Review

\title{
Seascape ecology in Posidonia oceanica seagrass meadows: Linking structure and ecological processes for management
}

\author{
Arnaud Abadie $^{\mathrm{a}, *}$, Matthew Pace ${ }^{\mathrm{b}}$, Sylvie Gobert ${ }^{\mathrm{a}}$, Joseph A. Borg ${ }^{\mathrm{b}}$

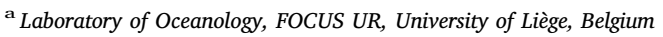 \\ b Department of Biology, Faculty of Science, University of Malta, Msida MSD2080, Malta
}

\section{A R T I C L E I N F O}

\section{Keywords:}

Seagrass

Seascape

Posidonia oceanica

Management

Structure

Function

Conservation

\begin{abstract}
A B S T R A C T
Seagrass meadows constitute marine habitats in shallow water temperate and tropical coastal areas worldwide that have a high ecological and economic importance. Amongst the 60 or so seagrass species, the endemic Mediterranean species Posidonia oceanica forms meadows that are arguably the most important shallow water coastal habitat in the region but which are subjected to high anthropogenic pressures. Because of the relatively large size of the plant, the meadows formed by this seagrass have high architectural and morphological complexity, which results in different morphotypes or seascapes. While numerous studies of $P$. oceanica architectural characteristics for continuous meadows of the seagrass are available, few works have addressed seascape ecological features and the influence of environmental factors (natural and anthropogenic) thereon. In the present review, we give an overview of $P$. oceanica meadow architectural and morphological characteristics and how these contribute to Mediterranean landscapes and seascapes. Studies addressing the influence of natural and anthropogenic factors on morphometric features of different meadow types and landscape ecological characteristics of $P$. oceanica habitat are also reviewed, as well as their influence on ecosystem processes. Finally, by considering the available data and tools for seascape studies, we present a discussion on methods to assess seagrass seascapes within the framework of coastal management. Our review highlights several gaps in $P$. oceanica seascape ecology knowledge such as the lack of data on the spatial distribution of this engineer species, and the possibility to use modern techniques and procedures for analysing structural and ecosystemic data.
\end{abstract}

\section{Introduction}

A landscape can be defined as a shifting arrangement of biotic structures and the resulting mosaic of patches (Fig. 1) (Robbins and Bell, 1994). In turn, the patches are surrounded by a border called an 'edge' (Fig. 1), which delimits different adjacent habitats (Pickett and Cadenasso, 1995). The whole structure is embedded within a matrix which plays a major role in connecting patches, thus ensuring landscape functioning (Fig. 1) (Forman and Godron, 1986). Within this context, landscape (or 'seascape' when dealing with marine habitats) ecologists aim to study the structure (morphology and size), function (functional ecology) and changes (evolution) of these biotic systems (Turner, 1989). Moreover, recent advances have identified two ways to consider the study of seascape ecology: one similar to landscape ecology for coastal ecosystems; one designed for pelagic ecosystems and their specific spatial and temporal characteristics (Kavanaugh et al., 2016; Pittman, 2017).

The definition of a $P$. oceanica seascape (and more generally of any seagrass seascape) will vary according to substratum type e.g. sand, bare mat and rock (Pagès et al., 2014), while the meadows themselves also comprise a matrix (Abadie et al., 2015). Seagrass habitat structure can be viewed at various levels - from within-meadow architectural features to gross meadow morphology; the latter ranging from continuous to patchy. The function of seagrass seascapes includes the influence of meadow structure on the associated biota. Lastly, change corresponds to the evolution over time of seagrass habitat structure and/or function. All these aspects can be studied at various spatial scales, from a few centimetres to hundreds of kilometres. Hereafter, we use 'small scale' in the context of an area covering less than $1 \mathrm{~km}^{2}$, and 'large scale' within the context of an area larger than $10 \mathrm{~km}^{2}$.

The practical value of data from seascape studies is their use to manage marine habitats and to model their evolution, taking into account the ecosystems' key species (Boström et al., 2011). Although this approach is commonly used in terrestrial ecosystems management and conservation (Turner, 1989; Zonneveld, 1995), it is seldom applied to coastal seascapes (Li and Mander, 2009), including seagrass meadows (Pittman et al., 2011). In part, this results from the lack of available data on the link between the occurrence and distribution of species

\footnotetext{
* Corresponding author.

E-mail address: arnaudabadie@aol.fr (A. Abadie).
} 


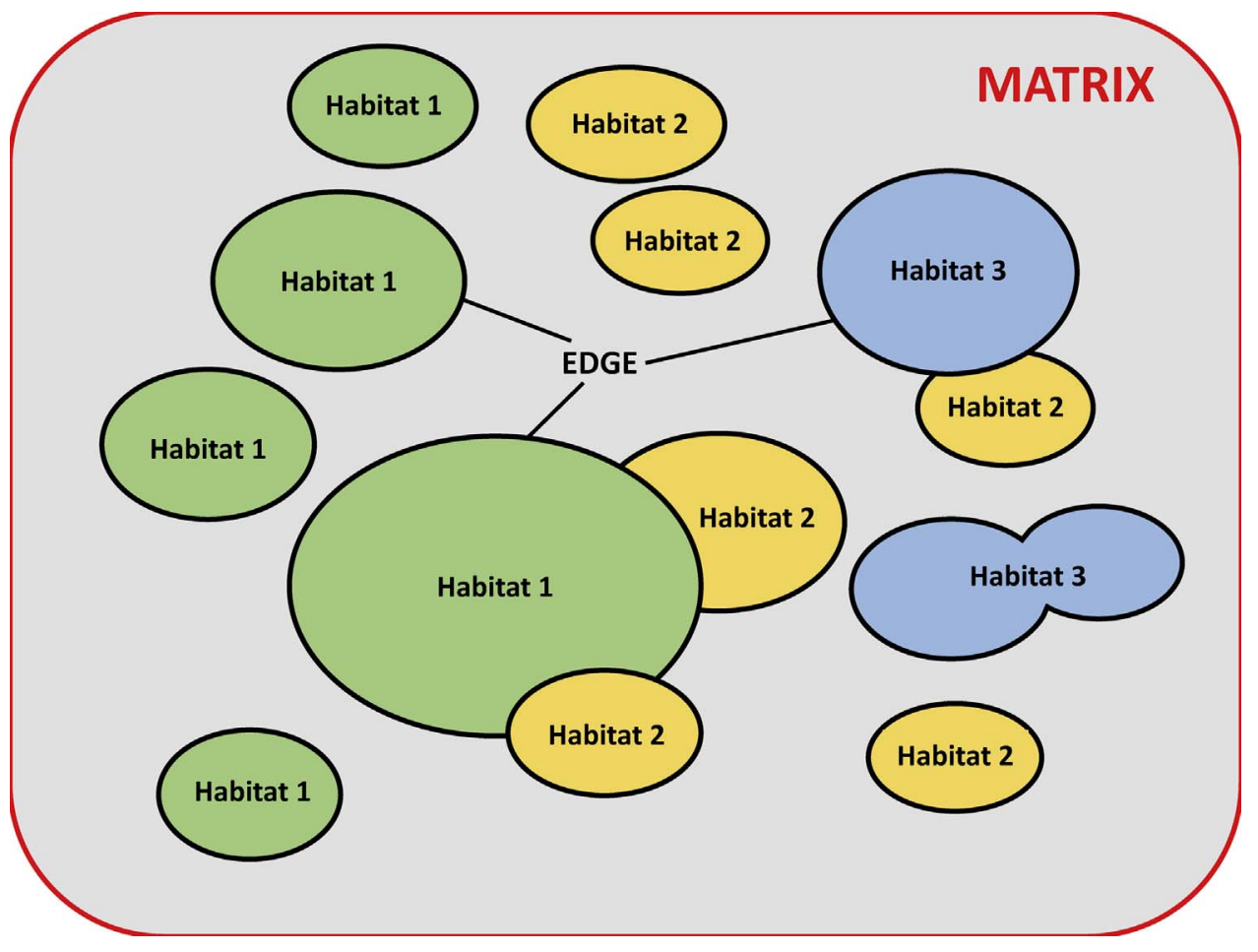

Fig. 1. Conceptual representation of different habitat compartments forming a landscape (or seascape).

associated with seagrass habitat and seagrass meadow structure (Boström et al., 2006).

The present work aims to highlight the importance of the seascape approach in the management of seagrass meadows through use of a well-documented species as example: $P$. oceanica. In the present work, we review previous seagrass seascape studies to: (1) highlight the main architectural characteristics of different $P$. oceanica meadow types; (2) identify the influence of main natural and anthropogenic factors on $P$. oceanica habitat; (3) describe the role played by $P$. oceanica seascapes on the associated biota; and (4) evaluate the contribution of $P$. oceanica meadows to the Mediterranean seascape. Finally, we identify gaps in knowledge and propose future work within the field of seascape ecology and management, as applied to $P$. oceanica and other seagrass habitats.

\section{Bibliographical research}

A bibliographical search of seagrass seascape studies was first undertaken without restricting to any one seagrass species. References to in situ studies were extracted from previous reviews concerning seagrass seascapes (Boström et al., 2006, 2011; Connolly and Hindell, 2006; Grober-Dunsmore et al., 2009; Heck et al., 2008; Horinouchi, 2007; Kendrick et al., 2005a; Vacchi et al., 2017). To complete this first approach, a search was then performed using the Scopus and Google Scholar data bases, using the keywords 'seagrass'; 'landscape'; 'seascape'; 'patch'; 'structure' and 'architecture'.

All references were then classified according to the field of study in seascape ecology, referring to the subjects of interest defined by Turner (1989), i.e. the structure (S), function (F) and changes (C). Furthermore, the method and spatial scale of each study was addressed by using a qualitative symbology scheme (Table 1).

\section{Posidonia oceanica seascape characteristics}

\subsection{Available literature on Posidonia oceanica seascape ecology}

The first work that makes reference to $P$. oceanica seascape was undertaken by Molinier and Picard (1952) along the French
Table 1

Symbology for sampling methods and spatial scales considered in seagrass meadow studies used in the present bibliographical search.

\begin{tabular}{lll}
\hline & Area & Symbol \\
\hline Method & & \\
Quadrats and sampling spots & Tens of $\mathrm{cm}^{2}$ & $\mathrm{Q}$ \\
Transects (scuba diving, video, trawling) & Hundreds of $\mathrm{m}^{2}$ & $\mathrm{~T}$ \\
Small patches & Less than $10 \mathrm{~m}^{2}$ & $\mathrm{SP}$ \\
Large patches & Tens of $\mathrm{m}^{2}$ & LP \\
Mapping (cartography, grid model) & Exhaustive & M \\
Area studied & & \\
Small scale & $<1 \mathrm{~km}^{2}$ & SSS \\
Medium scale & $1-10 \mathrm{~km}^{2}$ & MSS \\
Large scale & $>10 \mathrm{~km}^{2}$ & LSS \\
\hline
\end{tabular}

Mediterranean Coast. This study described 'intermatte' features, i.e. sand patches or channels present amongst the $P$. oceanica meadows and presumably resulting from the effects of bottom currents that are a residual product of wave action. Following this relatively early study, it was not before 1998 that the number of seagrass seascape studies started to increase (Fig. 2), reaching a total of 157 scientific works to date. The main species studied are Zostera marina and Posidonia oceanica; $23 \%$ and $34 \%$ of all published works respectively. When considering the total number of works reviewed (Fig. 3), studies carried out at the small spatial scale (SSS) are more numerous and comprise $53 \%$. However, studies carried out at large spatial scale (LSS) increased in number from the mid-2000s, reaching $30 \%$ of the total published works in recent years (Fig. 3). It is noteworthy that the first work undertaken at a large spatial scale was focused on P. oceanica (Pasqualini et al., 1998). When considering study methods, mapping (M) at various spatial scales appears to be the most popular methodology to study seagrass seascapes (40\%), followed by quadrat sampling and discrete sampling (Q-DS) techniques, which represent $27 \%$ of published works (Fig. 4). Details of the whole bibliographical search are available in the supplementary material Table SM1. 


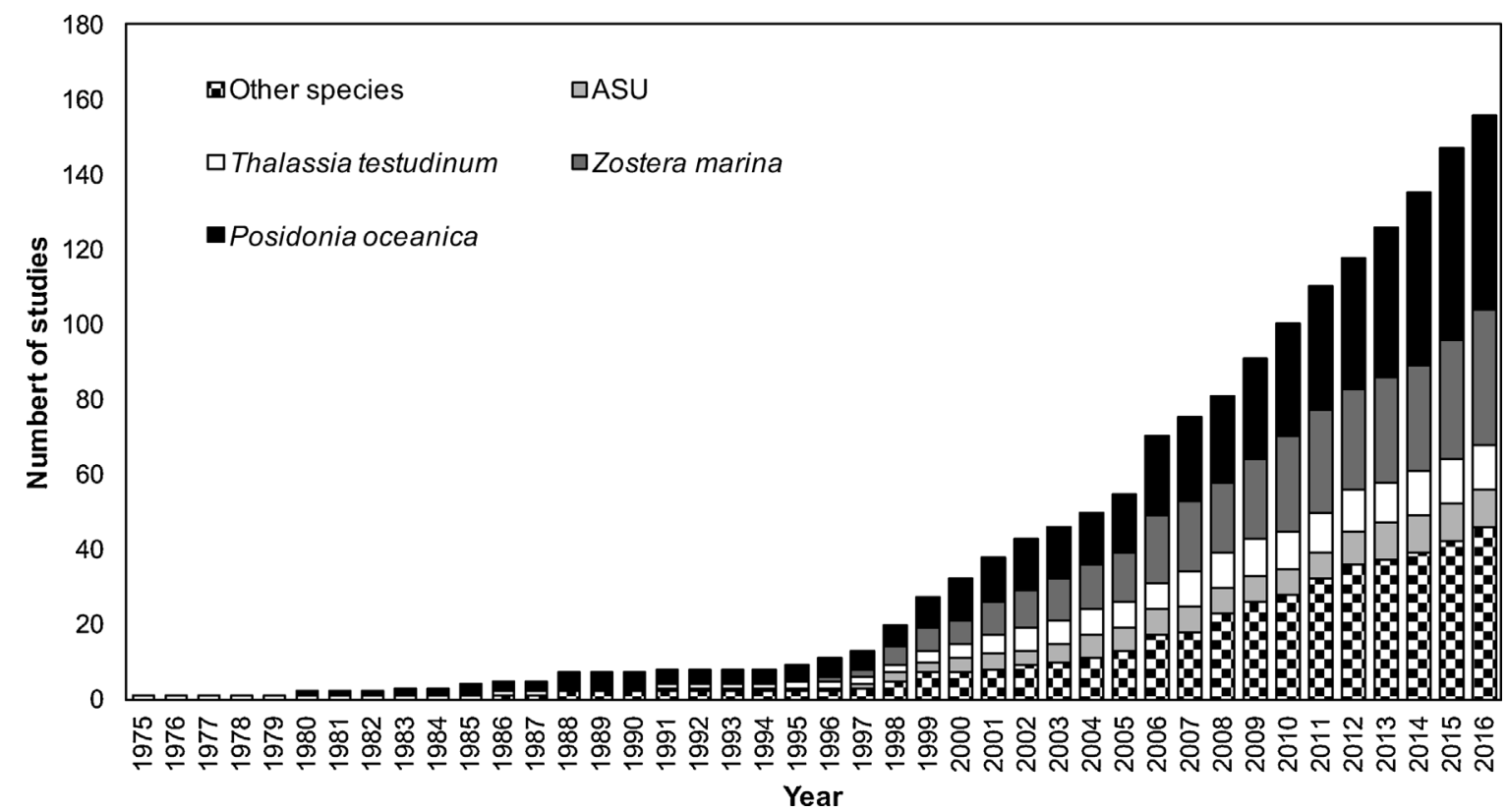

Fig. 2. Cumulative number of studies concerning seagrass seascape ecology published from 1975 to 2016. ASU: artificial seagrass unit.

\subsection{Posidonia oceanica within-meadow architectural characteristics}

Development of heterogeneous $P$. oceanica seascapes at the large spatial scale starts at the genetic level. More specifically, genetic diversity is correlated with meadow shoot density; the slow stolonization rate (asexual reproductive process of a $P$. oceanica shoot) over a long temporal scale leading to an increase of shoot density at the centre of isolated patches (Zupo et al., 2006a). The separation of two distinct branches on a single $P$. oceanica rhizome thus depends on an internal biological clock (Molenaar et al., 2000). After the development of new shoots, their orientation (orthotropic or plagiotropic) can be reversed (Molenaar et al., 2000) in order to adapt to change in environmental factors, such as sedimentation or the availability of unvegetated substrata that can be colonized. No competition is observed between the new shoots and no increase in leaf size is observed when shoot density decreases (Panayotidis et al., 1981). However, an opposite phenomenon in the growth characteristics of the plant is observed when taking into account the sediments chemistry (e.g. $\mathrm{pH}$, nutrients concentrations, redox potential) (Gobert, 2002). Differences in morphology, growth rate, leaf length and density mainly occur at small spatial scales (Balestri et al., 2003; Borg et al., 2005; Zupo et al., 2006b). Under disturbances, Marbà et al. (1996) reported a shoot recruitment rate of $P$. oceanica that was lower than the mortality rate, thus leading to a slowly decreasing shoot density.

Specific features of shoots making up $P$. oceanica seascapes that vary at a very small scale, i.e. $<1 \mathrm{~m}^{2}$, lead to changes in shoot density at a larger spatial scale. This assertion has been verified at the spatial scale of hundreds of meters by Gobert et al. (2003) who noted the largest variation of meadow structure between 8 and $12 \mathrm{~m}$ depth, and which were attributed to some internal plant mechanism. Borg et al. (2005), who compared the within-meadow structure of reticulate and continuous meadows, observed no differences between the two meadow types over different spatial scales. Differences in shoot density will lead to parts of a seagrass meadow that have less resistance against erosive

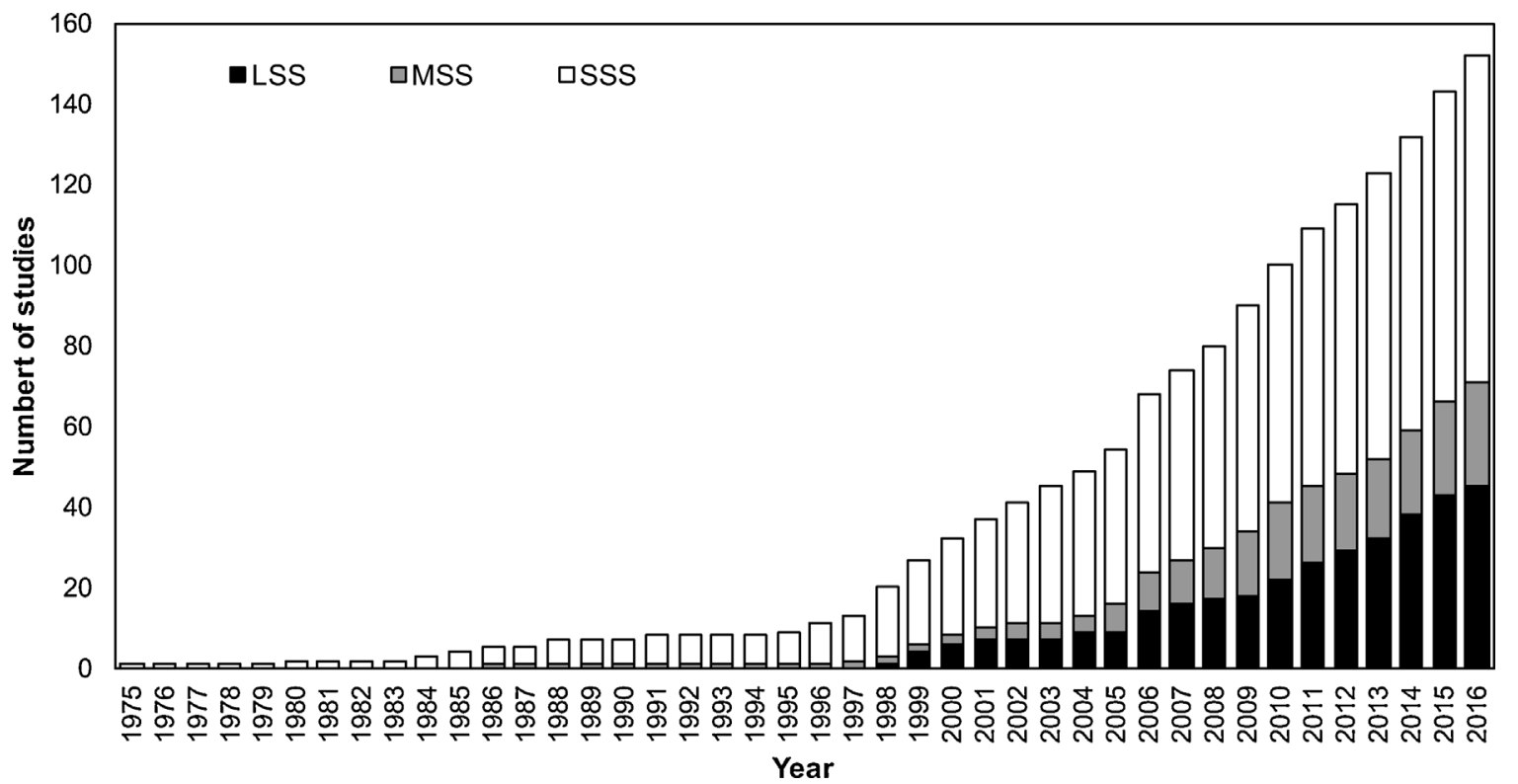

Fig. 3. Cumulative number of studies, categorized according to spatial scale addressed, published from 1975 to 2016 . LSS: large scale; MSS: medium scale; SSS: small scale. 


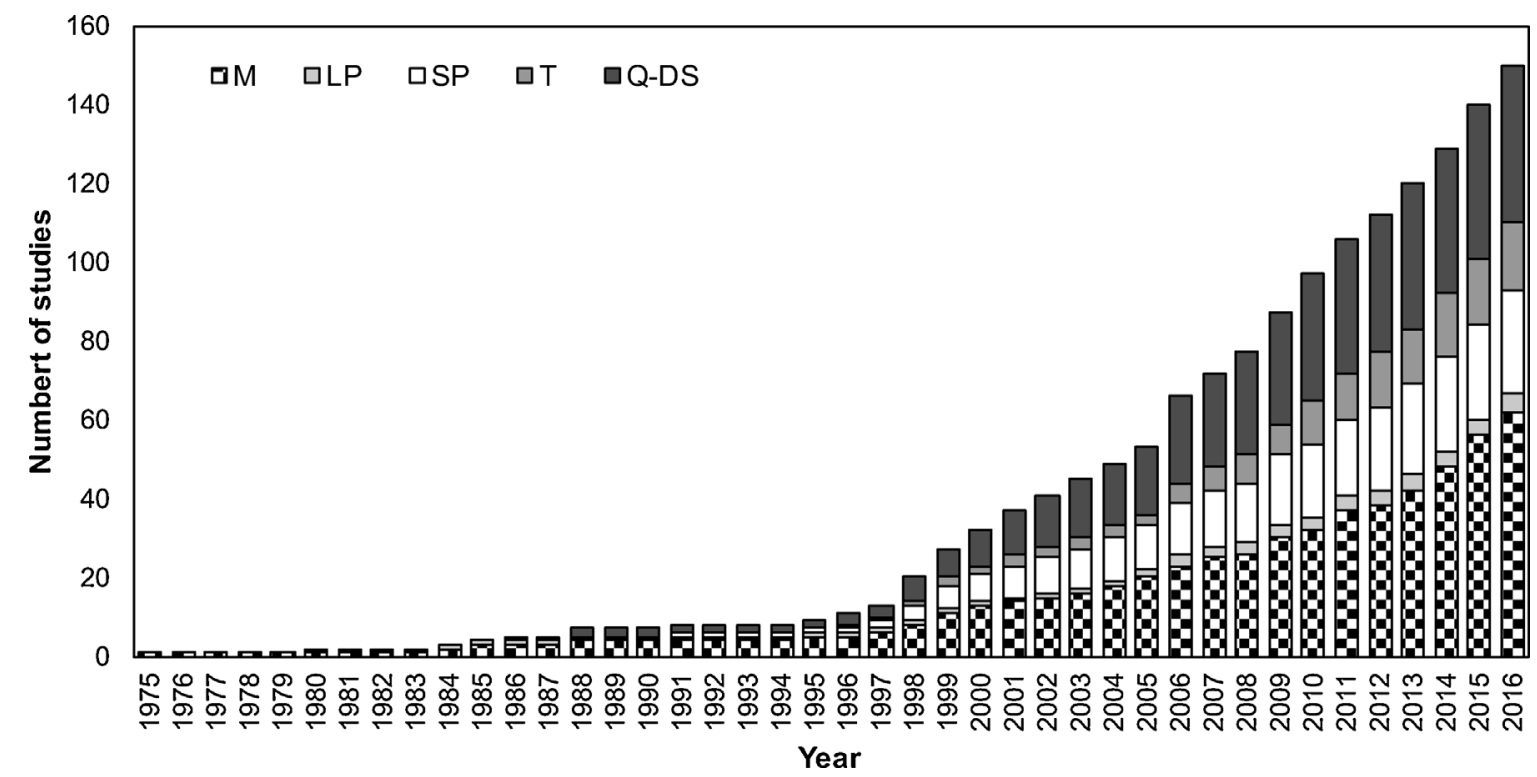

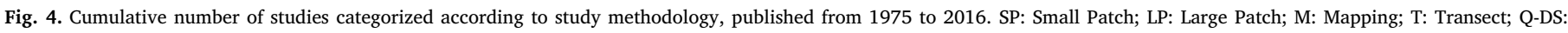
Quadrat-Discrete Sampling.

forces (e.g. sea currents and physical damage from anthropogenic activities), leading to the generation of patches at the seascape scale (Panayotidis et al., 1981) and development of different meadow morphotypes.

Far from being a flat and homogenous structure, $P$. oceanica meadows contribute to a seascape that is vertically structured because of their complex within-meadow architectural features. The leaf canopy acts as a trap of both organic and inorganic particles, with the leaves preventing their resuspension (Dauby et al., 1995). Gacia and Duarte (2001) assessed resuspension of particles within a $P$. oceanica meadow and noted that this was lower by a factor of 3 compared with a bare sediment bottom. The particle retention rate is increased by a factor of 5 during periods of exposure to erosion (e.g. during winter storms) (Gacia et al., 1999). Accumulation of the trapped sediment particle results in an elevation of the seabed, leading to corresponding vertical growth of $P$. oceanica rhizomes (Boudouresque et al., 1983; Boudouresque and Meinesz, 1982). The complex formed by sediments, living/dead roots and rhizomes is called "matte" (Boudouresque and Jeudy De Grissac, 1983; Gobert et al., 2006). This structural component, which can be several meters thick (López-Sáez et al., 2009), serves as an important carbon store (Mateo et al., 1997; Pedersen et al., 2011) while its dynamics are strongly linked to the seascape structure of $P$. oceanica meadows. Thus, the rhizome layer is sandwiched between the matte and leaf canopy.

\subsection{Impacts of natural and anthropogenic factors on Posidonia oceanica seascapes and within bed architecture}

Posidonia oceanica seascapes are strongly influenced by both natural and anthropogenic factors which determine their shape, and thus function, at various spatial scales.

Among natural factors, water movement, such as that associated with waves and currents, appears to be a main factor influencing the $P$. oceanica meadow structure at both within-meadow and seascape scales. However, this cannot always be verified as shown by Borg et al. (2009) who observed that high patchiness was not always linked with a high exposure.

At shallow water depths, strong bottom currents and the mechanical action generated by wave breaking prevent establishment of $P$. oceanica meadows. This has been confirmed by Infantes et al. (2009) who report that a current velocity higher than $40 \mathrm{~cm} \mathrm{~s}^{-1}$ compromises colonization by the plant. Similarly, Pace et al. (2017) show that at shallow depth (6-11 $\mathrm{m}$ depth), high energy wave climate leads to an increase of meadow patchiness and a decrease in architectural complexity. At greater water depths, even if negligible, currents derived from wave energy result in a decrease of meadow cover resulting in the generation of patches of different bottom type (bare matte or sandy bottom) (Abadie et al., 2017; Gobert et al., 2016; Vacchi et al., 2010). Furthermore, $P$. oceanica meadows enhance sediment stabilization of sandy patches present in their vicinity (Vacchi et al., 2017). At the large spatial scale, sandy patches intermixed within a $P$. oceanica meadow are clearly recognizable, as shown by side scan sonar images, and can occupy from $2 \%$ to $16 \%$ of the total seagrass meadow area (Abadie et al., 2015; Clabaut et al., 2014; Pasqualini et al., 2000; Pasqualini et al., 1999).

When considering smaller areas, e.g. a small bay $\left(<1 \mathrm{~km}^{2}\right.$ in size), other causes of meadow fragmentation, such as those resulting from wave action generated by high winds, are noted. As a result, sandy patches called "return river" (Boudouresque et al., 2012) can be generated within a $P$. oceanica meadow, the nature of which would depend on orientation of the coastal area concerned to the main winds influencing it (Boudouresque and Meinesz, 1982). Furthermore, such a situation can lead to an increase in the number of sandy patches present within a meadow (Abadie et al., 2015; Meinesz et al., 1988).

At the small spatial scale (i.e. several square meters) the architectural features of a $P$. oceanica meadows exhibit high heterogeneity because of several local natural factors such as nutrient availability, granulometry and pH (Borg et al., 2005; Gobert et al., 2003). External abiotic factors are coupled with internal ones, as well as structural features to lead to development of particular $P$. oceanica seascapes; one example is that described by Boudouresque et al. (1985) concerning the formation of a 'barrier reef', which results from long term sedimentation and the vertical growth rate of the plant (Fig. 5). In the same way, variation in horizontal growth of $P$. oceanica rhizomes leads to a heterogeneous seascape. This observation is based on a long term simulation which revealed colonization, over a period of 600 years, of an area measuring $0.3 \mathrm{ha}$, with the seascape being slowly modified throughout this period (Kendrick et al., 2005b). This process may not be a linearly dynamic one, with recruitment increasing with an increase in $P$. oceanica patch size (Almela et al., 2008). Seafloor morphology, as well as geology (e.g. sand, rock), also play an important role in determining seascape heterogeneity (Montefalcone et al., 2016). At the 

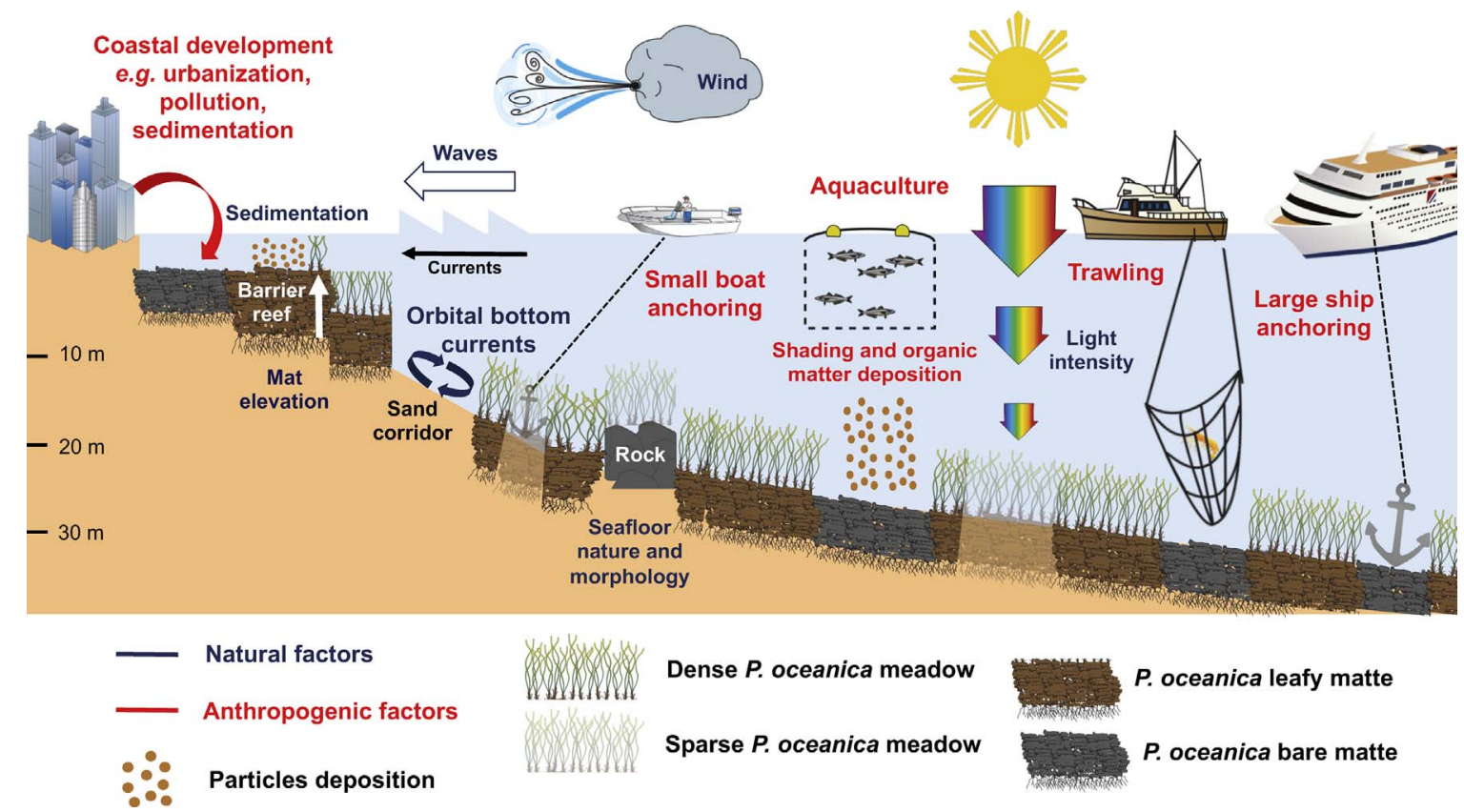

Dense $P$. oceanica meadow

Sparse $P$. oceanica meadow

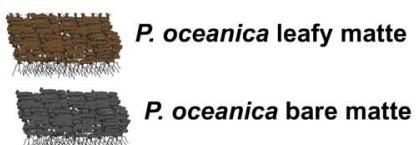

Fig. 5. Schematic diagram showing natural and anthropogenic factors that influence a $P$. oceanica seascape. The scale on the left indicates water depth.

level of shoot density and plant growth dynamics, local environmental factors may lead to a high degree of patchiness which is manifested as nestlike patterns (Zupo et al., 2006b). Similarly, decreased light intensity may lead to alteration of seascape micro-structure (see Fig. 5), as for example demonstrated by Dalla Via et al. (1998) who recorded a decrease of $72 \%$ in shoot density between a water depth of $3 \mathrm{~m}$ and $10 \mathrm{~m}$.

Human activities, such as coastal development, trawling, anchoring, fish farms, are well known to directly modify $P$. oceanica meadow structure at all depths (Boudouresque et al., 2009; Giakoumi et al., 2015), but such effects are less evident within the 35-43 m bathymetric range (Pasqualini et al., 1998). As in the case of naturally-occurring patches of the seagrass, patches resulting from anthropogenic activities can be clearly identified at a large spatial scale according to their size and shape (Abadie et al., 2015; Clabaut et al., 2014; Pasqualini et al., 1999).

In places characterized by intense human activities, anthropogenic impacts on $P$. oceanica habitat result in higher levels of fragmentation compared to natural processes (Leriche et al., 2006; Montefalcone et al., 2010b). However, in areas characterized by moderate anthropogenic pressures, $P$. oceanica seascapes have a relatively low percentage of patches that result from human impact. For example, in Corsica (France), patches resulting from anthropogenic impact comprise only a maximum $6 \%$ of the total seagrass area and no further significant regression has been recorded (Abadie et al., 2015; Bonacorsi et al., 2013).

In general, increased levels of anthropogenic impact favours the development of bare matte areas (Tamburello et al., 2012), leading to decreased $P$. oceanica patch size and edge length (Nowell, 2014). Anthropogenic impacts have different temporal scales of action, resulting in the creation of bare matte patches within the $P$. oceanica matrix. In the long term, if the adverse activities continue at the same intensity, a shift in the seagrass meadow matrix can occur, resulting in areas with bare sand or dead matte (Ardizzone et al., 2006). Among the human activities that operate over a long period to eventually lead to fragmentation of meadows, hence patch generation, are pressures linked with coastal development (pollution and high rates of sediment deposition, as well as urban expansion; see Fig. 5), will first lead to a decrease in shoot density and then to fragmentation of a $P$. oceanica meadow (Montefalcone et al., 2007, 2010b; Rountos et al., 2012). On the other hand, anthropogenic activities causing direct physical damage (e.g. boat anchoring, trawling, explosives) immediately lead to seagrass meadow fragmentation and to formation of patches (Fig. 5), thus modifying the seascape configuration (Kiparissis et al., 2011; Meinesz and Lefèvre, 1984; Okudan et al., 2011). Changes in the substratum's biogeochemistry as a result of mechanical damage can lead to intrusion of toxic compounds (e.g. hydrogen sulphide), which limit $P$. oceanica growth and meadow development (Abadie et al., 2016).

\subsection{Influence of P. oceanica seascapes on the associated biota}

As for meadows formed by other seagrass species, the occurrence and distribution of biota associated with a $P$. oceanica seascapes are mainly influenced by substratum type and meadow architecture (Boström et al., 2011). The transition between one habitat type and an adjacent different one and that delineating a patch of a given habitat type is called the 'edge' or 'ecotone' (Forman, 1995). For several species, their abundance tends to be higher at such junction between two different habitats; a phenomenon termed the 'edge effect' (Odum and Barrett, 1971). Edge effects have been given considerable attention in recent studies within seascape ecology that have been aimed at linking meadow or patch structure to the species' distribution, with emphasis on a particular taxon, assemblage, or functional trait (Boström et al., 2006).

Benthic communities are known to change according to environmental characteristics, including substratum type, and anthropogenic influences (Borja et al., 2003; Eagle, 1975). This has been confirmed in studies of interactions between $P$. oceanica meadows and bare sediment bottoms, the results of which have indicated a higher diversity and abundance of epifauna at the edge of a seagrass meadow (Fig. 6). For example, mysids prefer the meadow edge, while other taxa show no specific preference for location within a habitat except at the level of the species (Sánchez-Jerez et al., 1999). Settlement of non-mobile benthic species like Pinna nobilis Linnaeus also shows a strong edge effect, with more than half of the bivalve population found at the border of a P. oceanica meadow (Coppa et al., 2010). Therefore, the occurrence and distribution of $P$. nobilis appears to be greatly influenced by seagrass meadow form and structure within a seascape.

Amongst the substrata associated with $P$. oceanica meadows, dead matte (resulting from both natural or anthropogenic factors), although classically considered as an impoverished substratum in terms of the 


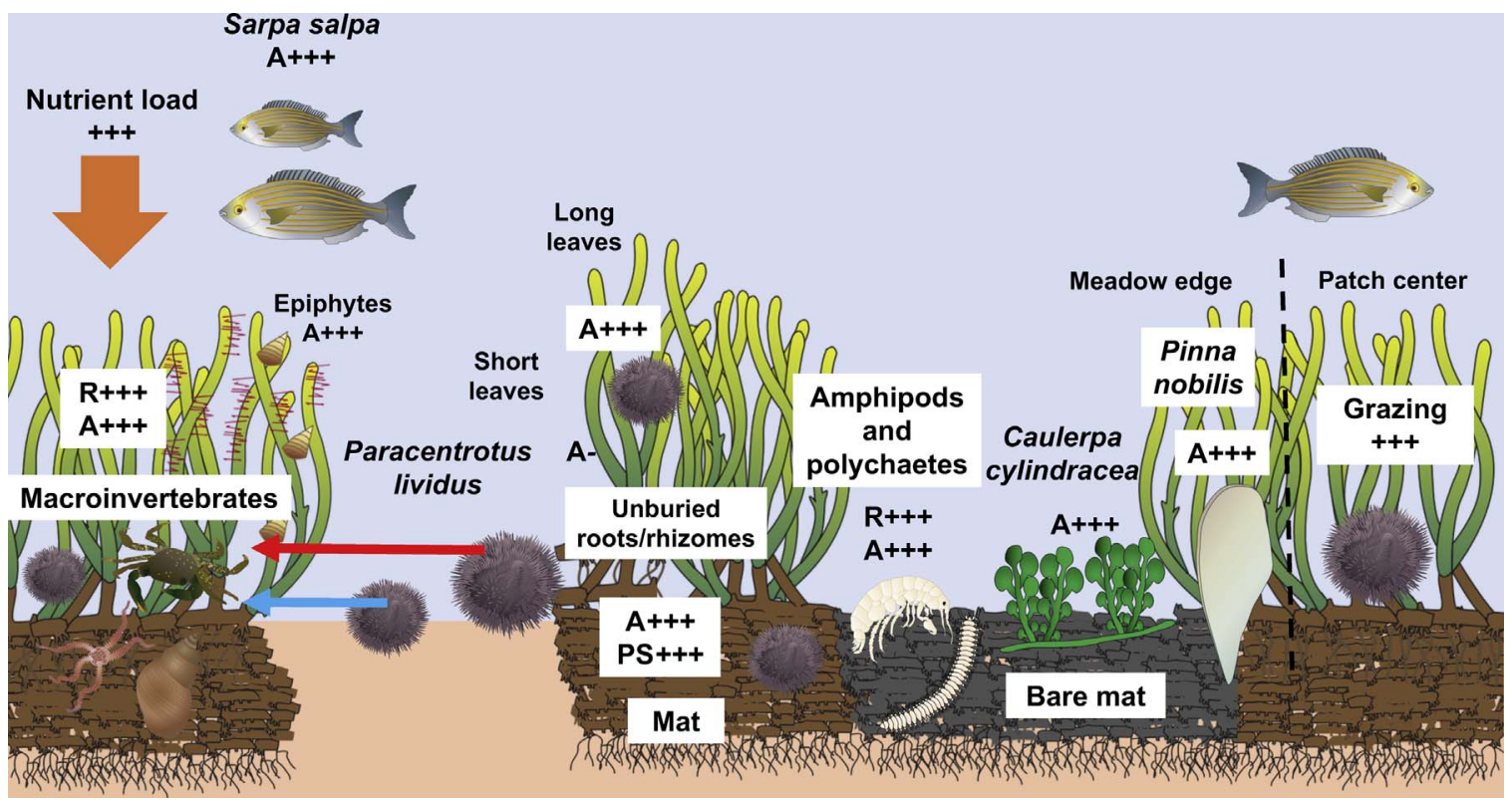

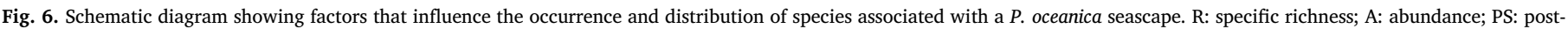
settlement.

biota it supports, have been noted to support a similar species richness compared with living matte (Fig. 6). For example, Borg et al. (2006) highlighted differences in the assemblage structure of macroinvertebrates associated with naturally-occurring dead matte; a higher abundance of the amphipods Leptocheirus guttatus Grube and Maera grossimana Montagu, and the polychaeta Nereis rava Ehlers were recorded from this substratum type compared to living matte of healthy $P$. oceanica meadows. (Coppa et al., 2010) noted that populations of the bivalve $P$. nobilis have a higher density on bare matte (Fig. 6) compared to living matte of $P$. oceanica and bare sand. In the case of dead matte resulting from anthropogenic activities such as illegal trawling, differences in population densities at microscale level $(0.1-1 \mathrm{~m})$ have been recorded for amphipods and isopods when compared to the same groups associated with living matte (Sánchez-Jerez and Ramos Esplá, 1996).

In areas where a habitat is under the influence of nutrient enrichment, such as $P$. oceanica meadows located near fish farms, workers e.g. Dimech et al. (2002) have observed a localized increase in species richness and abundance as a result of increased productivity (Fig. 6); this despite a change in meadow structure which was evident by lower leaf length and shoot density of $P$. oceanica located near the fish farm. Therefore, meadow structure alone does not determine the occurrence and distribution of species associated with the seagrass, and other factors can modify the $P$. oceanica seascapes' function. Studies have also indicated that small modifications of seagrass meadow structure may not have an appreciable influence on the associated macroinvertebrate assemblages but these are more influenced by other factors such as epiphyte biomass and sediment grain size (Borg et al., 2010).

The most studied functional aspect of $P$. oceanica seascapes is that concerning grazing of the leaf canopy by herbivores. The largest grazers are sea urchins Paracentrotus lividus Lamarck and the saupe Sarpa salpa Linnaeus, which attract attention as a result of their ability to consume and digest large amounts of $P$. oceanica tissue (Peirano et al., 2001).

Study of the occurrence and distribution of benthic species often includes an assessment of their settlement preferences within the considered habitat. In P. oceanica seascapes, Prado et al. (2009) observed that one-year cohort individuals of $P$. lividus tend to prefer $P$. oceanica matte as post-settlement habitat (Fig. 6), and absence of this substratum led to $100 \%$ non-survival of the post-settled individuals. Still, this process would depend on the individuals' proximity to $P$. oceanica habitat despite their ability to move toward a meadow (Fig. 6). Furthermore, the process does not depend on seagrass patch size (Ceccherelli et al., 2009), suggesting that even young individuals can reach the matte. In this way, the abundance of $P$. lividus increases on the seagrass matte at the edge of a meadow (Pinna et al., 2013) where they are protected from fish predation by the longer leaves, as well as by the unburied portion of the rhizome layer (Farina et al., 2009).

When comparing the functional compartment of $P$. oceanica grazers, namely $S$. salpa, $P$. lividus and amphipods, all of which are motile consumers, it is not only the influence of meadow structure on their distribution which is useful for study but also their impact on seascape characteristics. For example, at the level of influence of seagrass meadow structure, Pagès et al. (2014) show that $P$. lividus and $S$. salpa increase their grazing pressure at the centre of $P$. oceanica patches rather that at their edge (Fig. 6). Such findings suggest that $P$. oceanica patches established on a rocky bottom are more subject to grazing than those present on a sandy bottom. The increase in grazing pressure, combined with natural fragmentation of the seagrass meadows, leads to loss of $P$. oceanica primary production (Gera et al., 2013).

The natural and human-induced heterogeneity of $P$. oceanica seascapes, for example where sand and bare matte patches are introduced within meadows of the seagrass, provide substrata for colonization by invasive and fast-growing non-indigenous species. In the Mediterranean Sea, this phenomenon has been especially studied for Chlorobionta of the genus Caulerpa. These species are able to substitute $P$. oceanica faster than native species, leading to a higher rate of fragmentation of meadows of the seagrass (Montefalcone et al., 2010a).

The first non-native species historically studied for its interaction with $P$. oceanica meadows is Caulerpa taxifolia (Vahl) C. Agardh; a circumtropical Chlorobionta member that was accidentally introduced in the north-western Mediterranean Sea (Jaubert et al., 2003). De Villèle and Verlaque (1995) observed that $C$. taxifolia established within a $P$. oceanica meadow causes demise of the seagrass, although plant to mortality decreases with an increase in shoot density. The higher $P$. oceanica shoot density has a shading effect on $C$. taxifolia blades, leading to a lower photosynthetic capacity and, hence, size of the alga and, by extension its colonization capacity (Ceccherelli and Cinelli, 1999). Based on several years of observation, Jaubert et al. (1999) reported no long-term impact of this alien alga on $P$. oceanica meadows invaded by this species. However, later it transpired that other 
competitive processes between $P$. oceanica and $C$. taxifolia do occur through the release of chemical compounds into the substratum, as these lead to changes in the growth pattern and structural development of the seagrass (Pergent et al., 2008). Currently, C. taxifolia has almost disappeared from sites previously colonized, its regression being ascribed to a decrease of its dispersion capacity (Montefalcone et al., 2015).

Another non-indigenous Chlorobionta species, Caulerpa cylindracea Sonder, originates from south-western Australia; its presence has been noted in the Mediterranean Sea since 1990 (Klein and Verlaque, 2008). This species tends to prefer patches of bare matte within a $P$. oceanica seascape (Fig. 6) rather than bare sediment and rocky bottoms (Katsanevakis et al., 2010). C. cylindracea also colonizes impacted habitats, such as those exposed to trawling activities, including $P$. oceanica meadows affected by the activity (Kiparissis et al., 2011). C. cylindracea has been noted to be unable to penetrate dense $P$. oceanica meadows and only remains established along their edges (Ceccherelli et al., 2000).

\subsection{Connectivity of Posidonia oceanica meadows with the Mediterranean seascape}

Landscape/seascape connectivity is well studied in tropical areas which support a triangular network of mangroves, coral reefs and seagrass meadows (Berkström et al., 2012; Grober-Dunsmore et al., 2009). Although connectivity between marine and terrestrial Mediterranean habitats has not been studies much at a large spatial scale, merging several isolated works provides an insight into the role played by $P$. oceanica meadows (Fig. 7). Through export of primary production (Boudouresque et al., 2015) and their influence on water movement (Vacchi et al., 2017), P. oceanica meadows interact with other habitats, both marine and terrestrial (Heck et al., 2008), thus connecting with the whole Mediterranean coastal landscape and seascape.

A Posidonia oceanica seascape is mainly linked with terrestrial habitats at the level of beaches. Through their structure, dense $P$. oceanica meadows attenuate wave energy in shallow depths (Manca et al., 2012). For example, Infantes et al. (2012) recorded a reduction of $50 \%$ of wave height in places where $P$. oceanica meadows had a density of around 600 shoots $\mathrm{m}^{-2}$. Moreover, by decreasing the wave energy reaching the shore, $P$. oceanica meadows limit the height of waves crashing on a beach (Manca et al., 2012). P. oceanica meadows therefore provide natural protection for beaches against coastal erosion (Gacia and Duarte, 2001; Vacchi et al., 2017).
Through exposure to water movement and its seasonal physiological characteristics, $P$. oceanica meadows export part of their primary production to the shore (Boudouresque et al., 2006); this process occurs mainly during autumn and winter storms. The exported material, which comprises leaves, roots and rhizomes, accumulate on sandy beaches and form 'banquettes' (Fig. 7) - a pile of $P$. oceanica litter that can reach a height of several meters (Boudouresque et al., 2015). Banquettes are eroded at their bases by waves, resulting in the formation of an arched overhang (Mateo et al., 2003), while they limit sediment loss from a beach, hence reducing coastal erosion (Chessa et al., 2000; De Falco et al., 2008). Banquettes act as temporary sinks of biogenic elements, given that $P$. oceanica meadows are able to accumulate $50 \%$ of their biomass, $71 \%$ of their carbon, $27 \%$ of their nitrogen and $9 \%$ of their phosphorous (Mateo et al., 2003). Slow degradation of beach banquettes releases nutrients that are then available for terrestrial organisms (Guala et al., 2006). Such nutrient input has been assessed for the upper beach and fore dune vegetation (Fig. 7), and found to enrich terrestrial plant tissues by a factor of 1.5 for nitrogen and up to a factor of 2 for phosphorous (Cardona and García, 2008; Del Vecchio et al., 2013). Such organic material is, however, of no benefit as food for beach macroinvertebrates, such as the sand hopper Talitrus saltator Montagu, as these do not feed on P. oceanica wrack. However, the physical structure of banquettes provides them with a shelter against predation and other adverse environmental factors (Colombini et al., 2009).

As already mentioned above, $P$. oceanica seascapes interact both with shallower and deeper marine ecosystems through export of detritus (Fig. 7). This output of $P$. oceanica ecosystems is called "necromass", i.e. exported primary producers, leaves, broken rhizomes and roots as well as drift macrophytes (Boudouresque et al., 2015). The amount of necromass exported ranges from 10 to $55 \%$ (Boudouresque et al., 2015), while this percentage varies strongly between one place and another; for instance 51-68\% recorded from Marseille (France) and 37-49\% from Ischia (Italy) (Pergent et al., 1997; Pergent et al., 1994). Differences in the amount of exported necromass probably result from differences in water movement intensity during autumn and winter storms (Remy, 2016), as well as from P. oceanica seascape structure, with patchy meadows accumulating less detritus than continuous ones (Ricart et al., 2015).

Although the primary production exported from $P$. oceanica meadows is well studied, data on its destination and use in other marine seascapes are scarce. Presumably, the first marine habitats taking advantage of this input are those located adjacent the seagrass meadows,

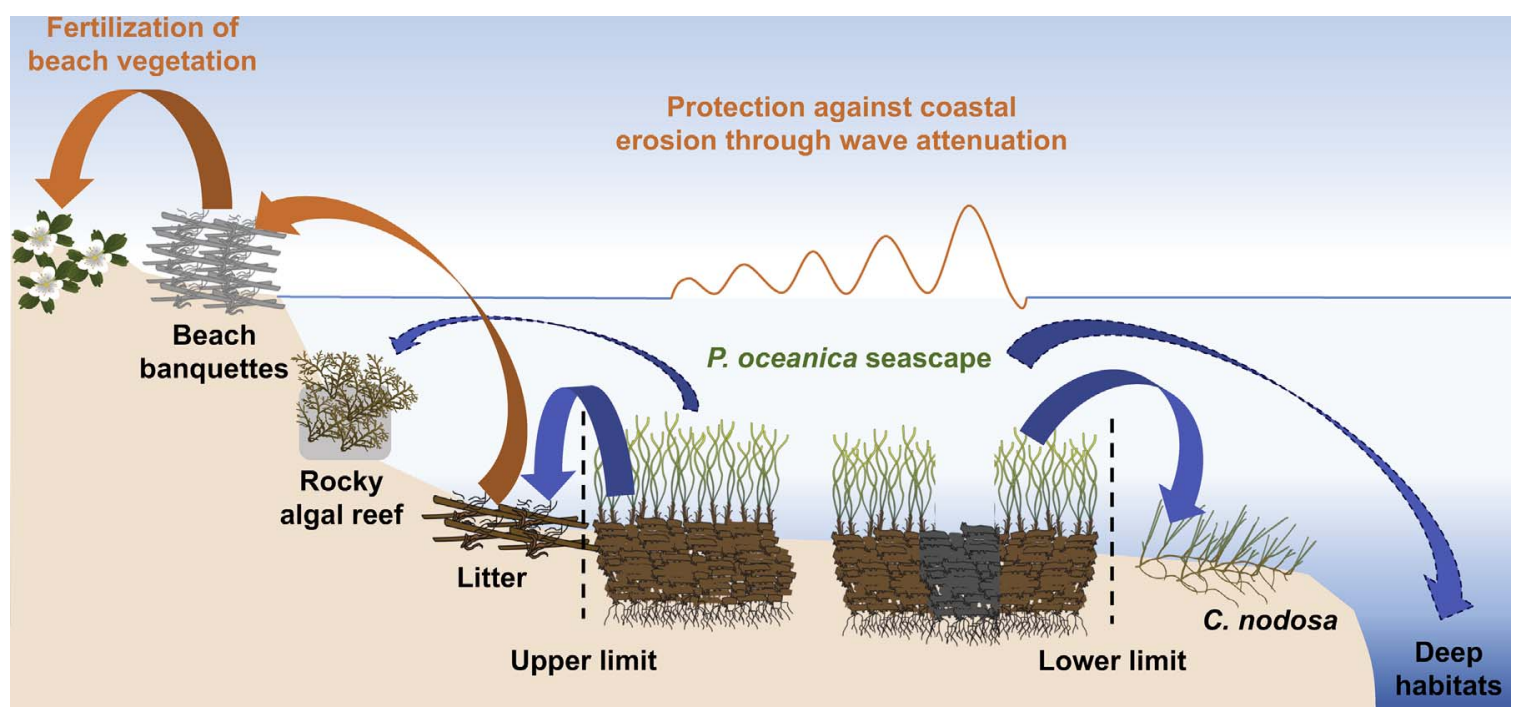

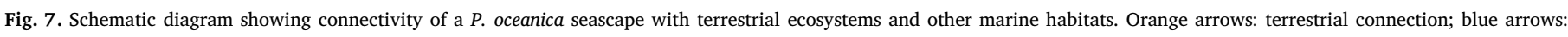
marine connection. (For interpretation of the references to colour in this figure legend, the reader is referred to the web version of this article.) 
for example bare sediment habitat, algal forests and meadows formed by other seagrass meadows (Fig. 7). Thus, P. oceanica outputs are a carbon source for sand-dwelling species living close to the meadow, while this has not been established for more distant ecosystems (Cardona et al., 2007). More than a simple food source, $P$. oceanica necromass, in the form of submerged 'litter' on the seabed, creates a temporary mobile habitat and provides a structured shelter for a whole unique set of detritivore invertebrates (Dimech et al., 2006; Mascart et al., 2015; Remy, 2016).

In the case of marine ecosystems located at a large distance from $P$. oceanica meadows, few studies have addressed the quantity and potential use of export of necromass from the seagrass ecosystem. It is assumed that most of this resource is consumed by the sea urchin Paracentrotus lividus present on sublittoral rocky bottoms and reefs (Verlaque and Nedelec, 1983) as well as serving as a source of organic matter for algal habitat on hard bottoms (Cardona et al., 2007) and marine caves (Picard, 1965). However, such export is probably less than expected given the lower efficiency of $P$. oceanica energy transfer (2-10 times lower) to higher trophic levels when compared to other Mediterranean seagrasses such as Cymodocea nodosa (Ucria) Ascherson and Zostera noltii Hornemann (Danovaro et al., 2002). Organic material exported by $P$. oceanica is also expected to reach deep water habitats to depths of around $600 \mathrm{~m}$ (Gobert, personal observation; Fig. 7) (Wolff, 1976).

\section{Information on $P$. oceanica seascapes for management purposes}

Although a large effort has been made to understand aspects of seascape ecology over the last fifteen years, there are still limitations with regard to both data acquisition and mining and treatment when compared with terrestrial landscape studies. Moreover, there remain difficulties concerning the development of tools for managers and stakeholders who, ultimately, are the eventual users of information on seagrass seascape ecology. These assertions are particularly true for Posidonia oceanica seascapes and their management within the framework of European directives such as the Water Framework Directive (WFD) and the Marine Strategy Framework Directive (MSFD).

\subsection{Data acquisition and treatment}

One of the most widespread tools used in landscape ecology to collect information at large spatial scales is habitat mapping. Currently, the most popular techniques used in habitat mapping use Geographical Information Systems (GIS). Improvement of data acquisition techniques in recent years has enabled the production of extensive marine habitat maps (Leriche et al., 2004; Noël et al., 2012), which have become as important as the mapping techniques used in terrestrial ecological studies and the information generated thereof. Side scan sonar images (or sonograms), have a high resolution when used in mapping surveys of the marine environment, and can give a clear visual indication of seascapes formed by $P$. oceanica meadows. This information can be used to highlight the impacts of human activities on seagrass beds (Abadie et al., 2015; Leriche et al., 2006; Pasqualini et al., 1999). However, since side scan sonar requires use of a towed device, it cannot be operated at depths shallower than $10 \mathrm{~m}$ (Augris and Clabaut, 2001), thus limiting data acquisition on extensive shallow coastal areas that support seagrass meadows. To counteract this limitation, side scan sonar images are used in conjunction with aerial and satellite imagery techniques that allow accurate determination of the distribution of seagrass meadows and patches of the habitat.

As already stated, $P$. oceanica seascapes present a heterogeneous vertical structure whose formation in influenced by seafloor features and dynamics of the seagrass matte. A tri-dimensional approach is required to study the structural and functional features of the habitat. Mapping techniques currently used in landscape and seascape ecology utilize the two-dimensional (2D) aspect because this is simpler to generate and requires less data than ones having a three-dimensional (3D) aspect. The creation of 3D maps is, however, very widespread in terrestrial environmental studies, especially in programs that have an educational or informative aim (Niedomysl et al., 2013; Schobesberger and Patterson, 2008). Besides the advantages and inconvenience of visual interpretations (Popelka and Brychtova, 2013), 3D maps provide different results compared to the $2 \mathrm{D}$ ones according to the topography of the site studied. Moreover, some metrics traditionally used with 2D maps remain applicable to 3D analyses but, still, it is essential to create new ones (Parrott et al., 2008; Wu et al., 2012).

In the marine environment, particularly in the case of seagrass meadows, site topography has a strong influence on the species' spatial distribution in different habitats (Robinson et al., 2011). Within the context of gathering information for use in conservation measures, use of 3D mapping surveys could help managers understand the importance and functioning of marine habitats. In the case of $P$. oceanica meadows, it is clearly established that water depth (Elkalay et al., 2003) and seafloor features (Di Carlo et al., 2005) play an essential role in influencing seagrass meadow dynamics. Thus, beyond the purely visual aspect, use of 3D maps in a seascape study should provide a more realistic view of patch arrangement and function. For instance, it seems logical that a $P$. oceanica vertical edge having a height of $2 \mathrm{~m}$ which appears flat on classical maps (2D) would constitute a real obstacle for the movement of several benthic organisms. Moreover, it is not only the aboveground structure that should be considered in a 3D analysis, but also the belowground one; namely the root-sediment matrix that also influences a $P$. oceanica seascape (Abadie et al., 2016).

The number of $P$. oceanica habitat mapping studies, as well as works assessing their functional role, have increased over the last two decades (Boström et al., 2011; Telesca et al., 2015). It would thus be tempting to extrapolate functional features at a large spatial scale from the available maps to manage coastal habitats. However, several obstacles prevent such approach for marine habitats in general, including $P$. oceanica seascapes.

Although the number of available maps of $P$. oceanica habitat has increased, there are still problems concerning lack of data on their functioning, and on how to acquire the necessary information. While it would seem appropriate to study structural and functional processes at a small spatial scale (i.e. smaller than $1 \mathrm{~km}^{2}$ ) using quadrats, discrete sampling techniques and transects (Pace et al., 2017), such techniques are less adequate for studies at the medium $\left(1-10 \mathrm{~km}^{2}\right)$ and large $\left(>10 \mathrm{~km}^{2}\right.$ ) spatial scales. A first obstacle thus lies in the methods used for large spatial scale studies. Even if $62 \%$ of such studies have relied on mapping, $20 \%$ of them have been made using quadrats and discrete sampling techniques (Table 2). Evidently, new field methods need to be developed to assess the functional aspect of seagrass seascapes at large spatial scales; for example, automated fish and macroinvertebrate counting made using Remotely Operated Vehicles.

Furthermore, as described above, sampling effort has been focused on a small number of species that have contrasting mobility (Boström et al., 2006; Connolly and Hindell, 2006). Linking direct observations with maps requires addressing aspects of interest indicated by a numerical data, such as width of the edge effect and maximal propagation/dispersal distance of species between one patch and another (Boström et al., 2011; Olds et al., 2016). Unfortunately, even on

Table 2

Proportion (\%) of sampling methods used in studies of $P$. oceanica that consider one or more spatial scales. SSS: Small Scale; MSS: medium scale; LSS: Large scale; Q-DS: Quadrat-Discrete Sampling; T: Transect; SP: Small Patch; LP: Large Patch; M: Mapping.

\begin{tabular}{llllll}
\hline & Q-DS & T & SP & LP & M \\
\hline SSS & 39 & 6 & 24 & 6 & 24 \\
MSS & 12 & 24 & 0 & 4 & 60 \\
LSS & 20 & 13 & 4 & 0 & 62 \\
\hline
\end{tabular}


obtaining such data, the information acquired using the available methods may not reflect the true situation due to the complexity of species-rich ecosystems such as P. oceanica seascapes (Duffy et al., 2007; Green and Sadedin, 2005). Such an obstacle can be overcome by using new approaches to data management and treatment based on meta-analysis of available data, which help answer a specific question. However, such an approach first requires homogenization of databases as well as total and free access to data resources; this field has been recently referred to as 'big science' (Hampton et al., 2013). When these conditions are met, it is possible to proceed with analysis of complex biological systems, such as $P$. oceanica seascapes, through data mining (Hochachka et al., 2007) and artificial intelligence (Rykiel, 1989). From fundamental approaches, new simplified tools and land/seascape assessment procedures aimed for use by coastal managers have already emerged; these indicate the limitations of previous techniques.

\subsection{New analysis tools for management purposes}

Over the last few decades, several indices have been developed for use in landscape ecology to quantify the spatial features of terrestrial habitats (McGarigal et al., 2014; Schumaker, 1996). These metrics have been transferred to marine studies and are currently widely used for management of seagrass seascapes, including ones formed by $P$. oceanica (Chefaoui, 2014; Montefalcone et al., 2013; Sleeman et al., 2005). However, recent studies concerning terrestrial ecosystem conservation have highlighted their limits (Kupfer, 2012; Šímová and Gdulová, 2012) the same observation being made for seascapes (Manderson, 2016). Specifically, information on the relationship between some specific metrics and ecological processes (Fig. 8) are sometimes doubtful (Li and Wu, 2004). Consequently, landscape indices should not be used alone when studying $P$. oceanica seascapes, while the outcomes should not be considered as the ultimate tool for management decisions but rather require coupling with other landscape procedures and interpreted using knowledge of ecological processes (Fig. 8). The limitations of landscape indices also highlight the need for new practical ways to provide information on seascapes to stakeholders.

Traditionally studied as a patch mosaic, landscapes can also be described within the context of a more functional angle by using an approach called the 'landscape graph' (Fig. 9) (Kupfer, 2012). Applying the mathematical theory underlying landscape graphs to landscape ecology results in nodes (2D patches) connected by links (from the perimeter or the centre) inside a matrix (Fall et al., 2007). Links can be drawn as Euclidean distances (straight lines), and as lowest cost (for instance according to relief or habitats), or else weighted using ecological factors. Different graph types can be built and modelled, for example, making links between all nodes or only making nodes close to another (Galpern et al., 2011). The generation of landscape graphs requires the use of new metrics to study landscape characteristics. This type of model is, however, limited as it only takes into account the landscape connectivity characteristics but not habitat quality (Moilanen, 2011).

The use of landscape graphs for the study of $P$. oceanica seascapes will be an important breakthrough in understanding the influence of meadow structure on the occurrence and distribution of associated biota. Within the context of conservation and management, graphs will help us gain insight of important aspects (Galpern et al., 2011) such as: (1) nodes are connected in a seascape; (2) which patch types are important for connectivity; (3) which patches are important for connectivity; (4) how connectivity differs between graphs; (5) the threshold of aggregation within a landscape. The knowledge gained will be very useful for managers involved in the conservation and management of seagrass habitat. The Landscape Graphs Model thus allows better communication of knowledge on important ecological aspects with decision-makers (Bergsten, 2013).

\section{Flaw in conception of the arrangement analysis}

No proved relation between the arrangement and the phenomenon

Absence of relevance in the indices

Confusion between the scale of observation and the scale of analysis
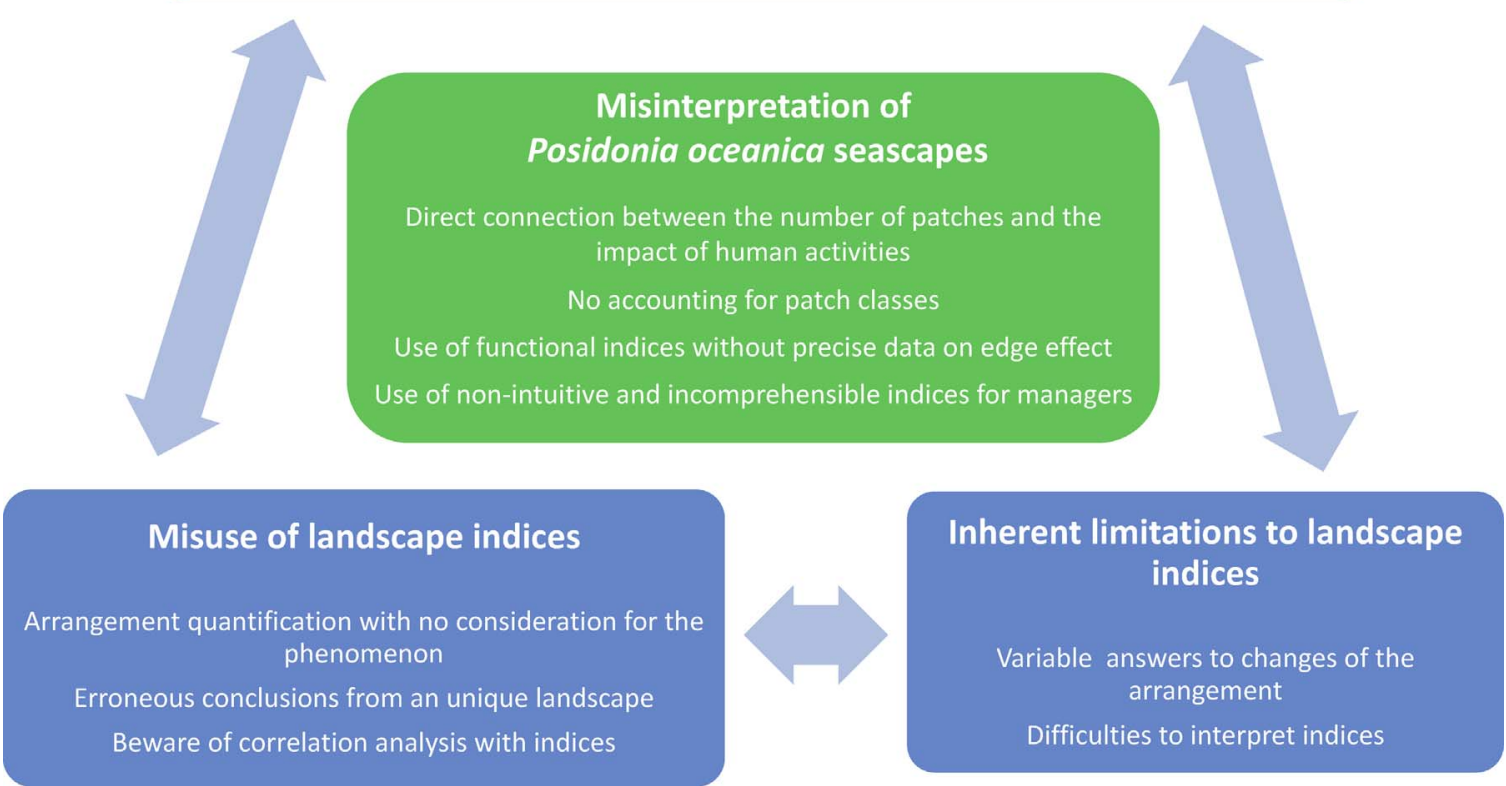

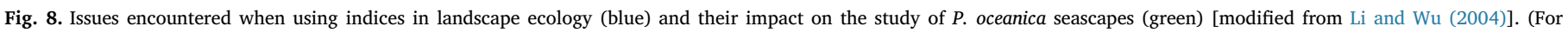
interpretation of the references to colour in this figure legend, the reader is referred to the web version of this article.) 


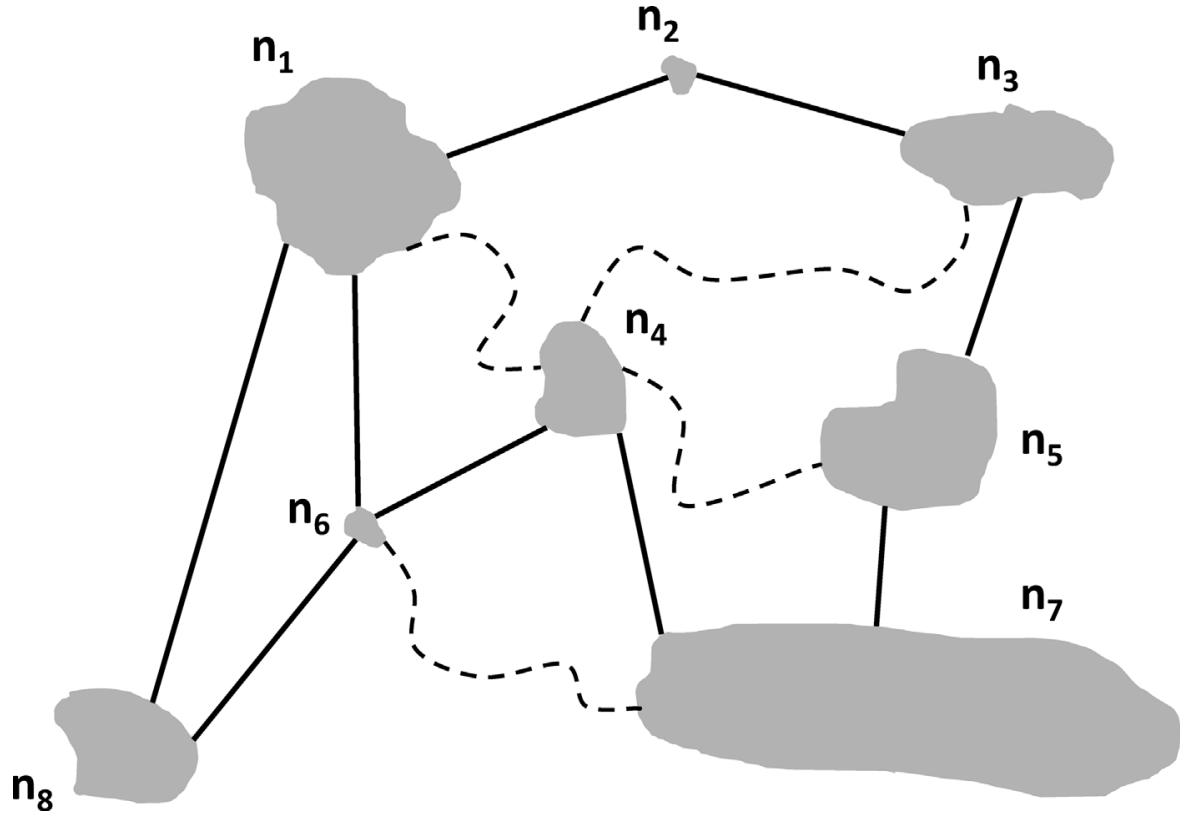

Fig. 9. Schematic diagram of the graph concept as applied to landscape ecology. Grey patches represent nodes (n), full black lines depict direct links (Euclidean distance) and dotted lines show links of lower cost.

\section{Conclusion}

Amongst the seascapes formed by different seagrasses, $P$. oceanica meadows are the most studied due to their peculiar and complex threedimensional structure and the large number of species they support. Over the last 15 years, there has been a large effort to study their largescale structural features and interactions with fauna and flora, which has resulted in important data being available for use in management of the habitat. However, much work remains to be done at the level of data processing as well as to enhance transfer of information on seagrass seascape ecology to managers and stakeholders. With this in mind, efforts to automatize the treatment of spatial and environmental data must be emphasized. New approaches and simplified procedures are currently available for landscape ecological studies but these cannot always be applied to seascape ecology due to lack of data. More specifically, there is gap in fundamental knowledge concerning the spatial distribution of key species (such as P. lividus and S. salpa) linked with the structure of seagrass seascapes. Hence, there is need for ecological studies aimed at gathering the necessary information as well as to develop new tools and procedures including ones aimed at studying $P$. oceanica seascapes. In the same way, critical environmental issues such as climate change and pollution may be studied including seascape aspects and thus provide a spatial and evolutionary point of view to coastal managers.

In a wider viewpoint, landscape ecology has become a bridge between scientists and stakeholders, thus allowing fundamental researches to be applied for conservation and management. When, dealing with seagrasses, especially with $P$. oceanica, seascape ecology seems promising for use in policies and protection enforcement, particularly given the increasing public interest on marine Magnoliophytes and the habitats they contribute to.

\section{Acknowledgements}

Arnaud Abadie acknowledges a CIFRE Ph.D. grant (2013/0470) of the French ANRT (Association Nationale Recherche Technologie). This study is part of the STARE-CAPMED (STAtion of Reference and rEsearch on Change of local and global Anthropogenic Pressures on Mediterranean Ecosystems Drifts) program funded by the Territorial Collectivity of Corsica and by The French Water Agency (PACACorsica). The authors thank the two anonymous reviewers who help to improve the manuscript quality through their comments.

\section{Appendix A. Supplementary data}

Supplementary data associated with this article can be found, in the online version, at https://doi.org/10.1016/j.ecolind.2017.12.029.

\section{References}

Abadie, A., Gobert, S., Bonacorsi, M., Lejeune, P., Pergent, G., Pergent-Martini, C., 2015 Marine space ecology and seagrasses. Does patch type matter in Posidonia oceanica seascapes? Ecol. Indic. 57, 435-446.

Abadie, A., Lejeune, P., Pergent, G., Gobert, S., 2016. From mechanical to chemical impact of anchoring in seagrasses: the premises of anthropogenic patch generation in Posidonia oceanica meadows. Mar. Pollut. Bull. 109, 61-71.

Abadie, A., Borges, A.V., Champenois, W., Gobert, S., 2017. Natural patches in Posidonia oceanica meadows: the seasonal biogeochemical pore water characteristics of two edge types. Mar. Biol. 164, 166.

Almela, E.D., Marbà, N., Álvarez, E., Santiago, R., Martínez, R., Duarte, C.M., 2008. Patch dynamics of the Mediterranean seagrass Posidonia oceanica: implications for recolonisation process. Aquat. Bot. 89, 397-403.

Ardizzone, G., Belluscio, A., Maiorano, L., 2006. Long-term change in the structure of a Posidonia oceanica landscape and its reference for a monitoring plan. Mar. Ecol. 27, 299-309.

Augris, C., Clabaut, P., 2001. Cartographie géologique des fonds marins côtiers. Exemples le long du littoral français. IFREMER p. 77.

Balestri, E., Cinelli, F., Lardicci, C., 2003. Spatial variation in Posidonia oceanica structural, morphological and dynamic features in a northwestern Mediterranean coastal area: a multi-scale analysis. Mar. Ecol. Prog. Ser. 250, 51-60.

Bergsten, A., 2013. Spatial Complexity and Fit Between Ecology and Management: Making Sense of Patterns in Fragmented Landscapes. Stockholm University, Stockholm, Sweden p. 30

Berkström, C., Gullström, M., Lindborg, R., Mwandya, A.W., Yahya, S.A.S., Kautsky, N., Nyström, M., 2012. Exploring 'knowns' and 'unknowns' in tropical seascape connectivity with insights from East African coral reefs. Estuar. Coast. Shelf Sci. 107, $1-21$.

Bonacorsi, M., Pergent-Martini, C., Breand, N., Pergent, G., 2013. Is Posidonia oceanica regression a general feature in the Mediterranean Sea? Mediterr. Mar. Sci. 14, 193-203.

Borg, J.A., Attrill, M.J., Rowden, A.A., Schembri, P.J., Jones, M.B., 2005. Architectural characteristics of two bed types of the seagrass Posidonia oceanica over different spatial scales. Estuar. Coast. Shelf Sci. 62, 667-678.

Borg, J.A., Rowden, A.A., Attrill, M.J., Schembri, P.J., Jones, M.B., 2006. Wanted dead or alive: high diversity of macroinvertebrates associated with living and 'dead' Posidonia oceanica matte. Mar. Biol. 667-677.

Borg, J.A., Rowden, A.A., Attrill, M.J., Schembri, P.J., Jones, M.B., 2009. Occurrence and distribution of different bed types of seagrass Posidonia oceanica around the Maltese Islands. Mediterr. Mar. Sci. 10.

Borg, J.A., Rowden, A.A., Attrill, M.J., Schembri, P.J., Jones, M.B., 2010. Spatial variation in the composition of motile macroinvertebrate assemblages associated with two bed types of the seagrass Posidonia oceanica. Mar. Ecol. Prog. Ser. 406, 91-104.

Borja, A., Muxika, I., Franco, J., 2003. The application of a Marine Biotic Index to different impact sources affecting soft-bottom benthic communities along European coasts. Mar. Pollut. Bull. 46, 835-845. 
Boström, C., Jackson, E.L., Simenstad, C.A., 2006. Seagrass landscapes and their effects on associated fauna: a review. Estuar. Coast. Shelf Sci. 68, 383-403.

Boström, C., Pittman, S.J., Simenstad, C.A., Kneib, R.T., 2011. Seascape ecology of coastal biogenic habitats: advances, gaps, and challenges. Mar. Ecol. Prog. Ser. 427, 191-217.

Boudouresque, C.F., Jeudy De Grissac, A., 1983. L'herbier à Posidonia oceanica en Méditerranée: les interactions entre la plante et le sédiment. Journal de Recherche Océanographique 8, 99-122.

Boudouresque, C.F., Meinesz, A., 1982. Découverte de l'herbier de posidonie, France. Boudouresque, C.F., Jeudy De Grissac, A., Meinesz, A., 1983. Relations entre la sédimentation et l'allongement des rhizomes orthotropes de Posidonia oceanica dans la baie d'Elbu (Corse). In: Boudouresque, C.F., Jeudy De Grissac, A., Olivier, J. (Eds.), International Workshop on Posidonia oceanica Beds. G.I.S. Posidonie, Marseille, pp. 185-191.

Boudouresque, C.F., Meinesz, A., Lefèvre, J.R., 1985. Cartographie des peuplements benthiques marins de Corse: I. la formation récifale à Posidonia oceanica de SaintFlorent. Ann. Inst. Oceanogr. 61, 27-38.

Boudouresque, C.F., Mayot, N., Pergent, G., 2006. The outsanding traits of the functioning of the Posidonia oceanica seagrass ecosystem. Biol. Mar. Mediterr. 13, 109-113.

Boudouresque, C.F., Bernard, G., Pergent, G., Shili, A., Verlaque, M., 2009. Regression of Mediterranean seagrasses caused by natural processes and anthropogenic disturbances and stress: a critical review. Bot. Mar. 52, 395-418.

Boudouresque, C.F., Bernard, G., Bonhomme, P., Charbonnel, E., Diviacco, G., Meinesz, A., Pergent, G., Pergent-Martini, C., Ruitton, S., Tunesi, L., 2012. Protection and Conservation of Posidonia oceanica Meadows. RAMOGE pub., Tunis.

Boudouresque, C.F., Pergent, G., Pergent-Martini, C., Ruitton, S., Thibaut, T., Verlaque, M., 2015. The necromass of the Posidonia oceanica seagrass meadow: fate, role, ecosystem services and vulnerability. Hydrobiologia 1-18.

Cardona, L., García, M., 2008. Beach-cast seagrass material fertilizes the foredune vegetation of Mediterranean coastal dunes. Acta Oecol. 34, 97-103.

Cardona, L., Revelles, M., Sales, M., Aguilar, A., Borrell, A., 2007. Meadows of the seagrass Posidonia oceanica are a significant source of organic matter for adjoining ecosystems. Mar. Ecol. Prog. Ser. 335, 123-131.

Ceccherelli, G., Cinelli, F., 1999. Effects of Posidonia oceanica canopy on Caulerpa taxifolia size in a north-western Mediterranean bay. J. Exp. Mar. Biol. Ecol. 240, 19-36.

Ceccherelli, G., Piazzi, L., Cinelli, F., 2000. Response of the non-indigenous Caulerpa racemosa (Forsskål) J. Agardh to the native seagrass Posidonia oceanica (L.) Delile: effect of density of shoots and orientation of edges of meadows. J. Exp. Mar. Biol. Ecol. 243, 227-240.

Ceccherelli, G., Pais, A., Pinna, S., Serra, S., Sechi, N., 2009. On the movement of the sea urchin Paracentrotus lividus towards Posidonia oceanica seagrass patches. J. Shellf. Res. 28, 397-403.

Chefaoui, R.M., 2014. Landscape metrics as indicators of coastal morphology: a multiscale approach. Ecol. Indic. 45, 139-147.

Chessa, L.A., Fustier, V., Fernandez, C., Mura, F., Pais, A., Pergent, G., Serra, S., Vitale, L., 2000. Contribution to the knowledge of banquettes' of Posidonia oceanica (L.) Delile in Sardinia Island. Biol. Mar. Mediterr. 7, 35-38.

Clabaut, P., Augris, C., Pergent, G., Pergent-Martini, C., Pasqualini, V., Bonacorsi, M., 2014. Les fonds marins côtiers de Corse. Cartographie biomorphosédimentaire. Editions Quae.

Colombini, I., Mateo, M.Á., Serrano, O., Fallaci, M., Gagnarli, E., Serrano, L., Chelazzi, L., 2009. On the role of Posidonia oceanica beach wrack for macroinvertebrates of a Tyrrhenian sandy shore. Acta Oecol. 35, 32-44.

Connolly, R.M., Hindell, J.S., 2006. Review of nekton patterns and ecological processes in seagrass landscapes. Estuar. Coast. Shelf Sci. 68, 433-444.

Coppa, S., Guala, I., De Lucia, G.A., Massaro, G., Bressan, M., 2010. Density and distribution patterns of the endangered species Pinna nobilis within a Posidonia oceanica meadow in the Gulf of Oristano (Italy). J. Mar. Biol. Assoc. U. K. 90, 885-894.

Dalla Via, J., Sturmbauer, C., Schönweger, G., Soetz, E., Mathekowitsch, S., Stifter, M., Rieger, R., 1998. Light gradients and meadow structure in Posidonia oceanica: ecomorphological and functional correlates. Mar. Ecol. Prog. Ser. 163, 267-278.

Danovaro, R., Gambi, C., Mirto, S., 2002. Meiofaunal production and energy transfer efficiency in a seagrass Posidonia oceanica bed in the western Mediterranean. Mar. Ecol. Prog. Ser. 234, 95-104.

Dauby, P., Bale, A.J., Bloomer, N., Canon, C., Ling, R.D., Norro, A., Robertson, J.E., Simon, A., Théate, J.M., Watson, A.J., Frankignoulle, M., 1995. Particle fluxes over a Mediterranean seagrass bed: a one year case study. Mar. Ecol. Prog. Ser. 126, 233-246.

De Falco, G., Simeone, S., Baroli, M., 2008. Management of beach-cast Posidonia oceanica seagrass on the island of Sardinia (Italy, Western Mediterranean). J. Coast. Res. 24, 69-75.

De Villèle, X., Verlaque, M., 1995. Changes and degradation in a Posidonia oceanica bed invaded by the introduced tropical alga Caulerpa taxifolia in the north western Mediterranean. Bot. Mar. 38, 79-88.

Del Vecchio, S., Marbà, N., Acosta, A.T.R., Vignolo, C., Traveset, A., 2013. Effects of Posidonia oceanica beach-cast on germination, growth and nutrient uptake of coastal dune plants. PLoS One 8, e70607.

Di Carlo, G., Badalamenti, F., Jensen, A., Koch, E., Riggio, S., 2005. Colonisation process of vegetative fragments of Posidonia oceanica (L.) Delile on rubble mounds. Mar. Biol. $147,1261-1270$

Dimech, M., Borg, J.A., Schembri, P.J., 2002. Changes in the structure of a Posidonia oceanica meadow and in the diversity of associated decapod, mollusc and echinoderm assemblages, resulting from inputs of waste from a marine fish farm (Malta, Central Mediterranean). Bull. Mar. Sci. 71, 1309-1321.

Dimech, M., Borg, J.A., Schembri, P.J., 2006. Motile macroinvertebrate assemblages associated with submerged Posidonia oceanica litter accumulations. Biol. Mar. Mediterr.
$13,130-133$.

Duffy, J.E., Cardinale, B.J., France, K.E., McIntyre, P.B., Thébault, E., Loreau, M., 2007. The functional role of biodiversity in ecosystems: incorporating trophic complexity. Ecol. Lett. 10, 522-538.

Eagle, R.A., 1975. Natural fluctuations in a soft bottom benthic community. J. Mar. Biol. Assoc. U. K. 55, 865-878.

Elkalay, K., Frangoulis, C., Skliris, N., Goffart, A., Gobert, S., Lepoint, G., Hecq, J.-H., 2003. A model of the seasonal dynamics of biomass and production of the seagrass Posidonia oceanica in the Bay of Calvi (Northwestern Mediterranean). Ecol. Model. $167,1-18$.

Fall, A., Fortin, M.J., Manseau, M., O’Brien, D., 2007. Spatial graphs: principles and applications for habitat connectivity. Ecosystems 10, 448-461.

Farina, S., Tomas, F., Prado, P., Romero, J., Alcoverro, T., 2009. Seagrass meadow structure alters interactions between the sea urchin Paracentrotus lividus and its predators. Mar. Ecol. Prog. Ser. 377, 131-137.

Forman, R.T.T., Godron, M., 1986. Landscape Ecology. John Wiley, New York.

Forman, R.T.T., 1995. Land Mosaics: The Ecology of Landscapes and Regions. Cambridge university press.

Gacia, E., Duarte, C.M., 2001. Sediment retention by a mediterranean Posidonia oceanica meadow: the balance between deposition and resuspension. Estuar. Coast. Shelf Sci. 52, 505-514.

Gacia, E., Granata, T.C., Duarte, C.M., 1999. An approach to measurement of particle flux and sediment retention within seagrass (Posidonia oceanica) meadows. Aquat. Bot. 65, 255-268.

Galpern, P., Manseau, M., Fall, A., 2011. Patch-based graphs of landscape connectivity A guide to construction, analysis and application for conservation. Biol. Conserv. 144, 44-55.

Gera, A., Pages, J.F., Romero, J., Alcoverro, T., 2013. Combined effects of fragmentation and herbivory on Posidonia oceanica seagrass ecosystems. J. Ecol. 101, 1053-1061.

Giakoumi, S., Halpern, B.S., Michel, L.N., Gobert, S., Sini, M., Boudouresque, C.F., Gambi, M.C., Katsanevakis, S., Lejeune, P., Montefalcone, M., Pergent, G., Pergent-Martini, C., Sanchez-Jerez, P., Velimirov, B., Vizzini, S., Abadie, A., Coll, M., Guidetti, P., Micheli, F., Possingham, H.P., 2015. Towards a framework for assessment and management of cumulative human impacts on marine food webs. Conserv. Biol. 29, 1228-1234.

Gobert, S., Kyramarios, M., Lepoint, G., Pergent-Martini, C., Bouquegneau, J.M., 2003. Variations à différentes échelles spatiales de l'herbier à Posidonia oceanica (L.) Delile; effets sur les paramètres physico-chimiques du sédiment. Oceanol. Acta 26, 199-207.

Gobert, S., Cambridge, M.L., Velimirov, B., Pergent, G., Lepoint, G., Bouquegneau, J.M., Dauby, P., Pergent-Martini, C., Walker, D.I., 2006. Biology of Posidonia, Seagrasses: Biology, Ecology, and Conservation. Springer, Dordrecht, The Netherlands, pp. 387-408.

Gobert, S., Lepoint, G., Pelaprat, C., Remy, F., Lejeune, P., Richir, J., Abadie, A., 2016. Temporal evolution of sand corridors in a Posidonia oceanica seascape: a 15-years study. Mediterr. Mar. Sci. 17, 777-784.

Gobert, S., 2002. Variations spatiale et temporelle de l'herbier à Posidonia oceanica (L.) Delile. Liège, p. 226

Green, D.G., Sadedin, S., 2005. Interactions matter-complexity in landscapes and ecosystems. Ecol. Complex. 2, 117-130.

Grober-Dunsmore, R., Pittman, S.J., Caldow, C., Kendall, M.S., Frazer, T.K., 2009. A landscape ecology approach for the study of ecological connectivity across tropical marine seascapes. In: Nagelkerken, I. (Ed.), Ecological Connectivity Among Tropical Coastal Ecosystems. Springer, Netherlands, pp. 493-530.

Guala, I., Simeone, S., Buia, M.C., Flagella, S., Baroli, M., De Falco, G., 2006. Posidonia oceanica 'banquettes' removal: environmental impact and management implications. Biol. Mar. Mediterr. 13, 149-153.

Hampton, S.E., Strasser, C.A., Tewksbury, J.J., Gram, W.K., Budden, A.E., Batcheller, A.L., Duke, C.S., Porter, J.H., 2013. Big data and the future of ecology. Front. Ecol. Environ. 11, 156-162.

Heck, K.L., Carruthers, T.J.B., Duarte, C.M., Hughes, A.R., Kendrick, G.A., Orth, R.J., Williams, S.W., 2008. Trophic transfers from seagrass meadows subsidize diverse marine and terrestrial consumers. Ecosystems 11, 1198-1210.

Hochachka, W.M., Caruana, R., Fink, D., Munson, A.R.T., Riedewald, M., Sorokina, D., Kelling, S., 2007. Data-mining discovery of pattern and process in ecological systems. J. Wildl. Manage. 71, 2427-2437.

Horinouchi, M., 2007. Review of the effects of within-patch scale structural complexity on seagrass fishes. J. Exp. Mar. Biol. Ecol. 350, 111-129.

Infantes, E., Terrados, J., Orfila, A., Cañellas, B., Álvarez-Ellacuria, A., 2009. Wave energy and the upper depth limit distribution of Posidonia oceanica. Bot. Mar. 52, 419-427.

Infantes, E., Orfila, A., Simarro, G., Terrados, J., Luhar, M., Nepf, H., 2012. Effect of a seagrass (Posidonia oceanica) meadow on wave propagation. Mar. Ecol. Prog. Ser. $456,63-72$.

Jaubert, J.M., Chisholm, J.R.M., Ducrot, D., Ripley, H.T., Roy, L., Passeron-Seitre, G., 1999. No deleterious alterations in Posidonia beds in the Bay of Menton (France) eight years after Caulerpa taxifolia colonization. J. Phycol. 35, 1113-1119.

Jaubert, J.M., Chisholm, J.R.M., Minghelli-Roman, A., Marchioretti, M., Morrow, J.H., Ripley, H.T., 2003. Re-evaluation of the extent of Caulerpa taxifolia development in the northern Mediterranean using airborne spectrographic sensing. Mar. Ecol. Prog. Ser. 263, 75-82.

Katsanevakis, S., Issaris, Y., Poursanidis, D., Thessalou-Legaki, M., 2010. Vulnerability of marine habitats to the invasive green alga Caulerpa racemosa var cylindracea within a marine protected area. Mar. Environ. Res. 70, 210-218.

Kavanaugh, M.T., Oliver, M.J., Chavez, F.P., Letelier, R.M., Muller-Karger, F.E., Doney, S.C., 2016. Seascapes as a new vernacular for pelagic ocean monitoring, management and conservation. ICES J. M. Sci.: J. Conseil 73, 1839-1850.

Kendrick, G.A., Duarte, C.M., Marbà, N., 2005a. Clonality in seagrasses, emergent 
properties and seagrass landscapes. Mar. Ecol. Prog. Ser. 290, 291-296.

Kendrick, G.A., Marbà, N., Duarte, C.M., 2005b. Modelling formation of complex topography by the seagrass Posidonia oceanica. Estuar. Coast. Shelf Sci. 65, 717-725.

Kiparissis, S., Fakiris, E., Papatheodorou, G., Geraga, M., Kornaros, M., Kapareliotis, A. Ferentinos, G., 2011. Illegal trawling and induced invasive algal spread as collaborative factors in a Posidonia oceanica meadow degradation. Biol. Invas. 13, 669-678.

Klein, J., Verlaque, M., 2008. The Caulerpa racemosa invasion: a critical review. Mar. Pollut. Bull. 56, 205-225.

Kupfer, J.A., 2012. Landscape ecology and biogeography: rethinking landscape metrics in a post-FRAGSTATS landscape. Prog. Phys. Geogr. 36, 400-420.

López-Sáez, J.A., López-Merino, L., Mateo, M.Á., Serrano, Ó., Pérez-Díaz, S., Serrano, L., 2009. Palaeoecological potential of the marine organic deposits of Posidonia oceanica: a case study in the NE Iberian Peninsula. Palaeogeogr. Palaeoclimatol. Palaeoecol. 271, 215-224.

Leriche, A., Boudouresque, C.F., Bernard, G., Bonhomme, P., Denis, J., 2004. A onecentury suite of seagrass bed maps: can we trust ancient maps? Estuar. Coast. Shelf Sci. 59, 353-362.

Leriche, A., Pasqualini, V., Boudouresque, C.F., Bernard, G., Bonhomme, P., Clabaut, P., Denis, J., 2006. Spatial, temporal and structural variations of a Posidonia oceanica seagrass meadow facing human activities. Aquat. Bot. 84, 287-293.

Li, X., Mander, U., 2009. Future options in landscape ecology: development and research. Prog. Phys. Geogr. 33, 31-48.

Li, H., Wu, J., 2004. Use and misuse of landscape indices. Landsc. Ecol. 19, 389-399.

Manca, E., Cáceres, I., Alsina, J.M., Stratigaki, V., Townend, I., Amos, C.L., 2012. Wave energy and wave-induced flow reduction by full-scale model Posidonia oceanica seagrass. Cont. Shelf Res. 50-51, 100-116.

Manderson, J.P., 2016. Seascapes are not landscapes: an analysis performed using Bernhard Riemann's rules. ICES J. Mar. Sci.: J. Conseil 73, 1831-1838.

Marbà, N., Duarte, C.M., Cebrian, J., Gallegos, M.E., Olesen, B., Sand-Jensen, K., 1996. Growth and population dynamics of Posidonia oceanica on the Spanish Mediterranean coast: elucidating seagrass decline. Mar. Ecol. Prog. Ser. 137, 203-213.

Mascart, T., Lepoint, G., Deschoemaeker, S., Binard, M., Remy, F., De Troch, M., 2015. Seasonal variability of meiofauna, especially harpacticoid copepods, in Posidonia oceanica macrophytodetritus accumulations. J. Sea Res. 95, 149-160.

Mateo, M.A., Romero, J., Perez, M., Littler, M.M., Littler, D.S., 1997. Dynamics of millenary organic deposits resulting from the growth of the Mediterranean seagrass Posidonia oceanica. Estuar. Coast. Shelf Sci. 44, 103-110.

Mateo, M.Á., Sánchez-Lizaso, J.L., Romero, J., 2003. Posidonia oceanica banquettes: a preliminary assessment of the relevance for meadow carbon and nutrients budget. Estuar. Coast. Shelf Sci. 56, 85-90.

McGarigal, K., Cushman, S.A., Ene, E., 2014. FRAGSTATS v4: Spatial Pattern Analysis Program for Categorical and Continuous Maps., pp. Computer software program produced by the authors at the University of Massachusetts, Amherst.

Meinesz, A., Lefèvre, J.R., 1984. Régénération d'un herbier à Posidonia oceanica quarante années après sa destruction par une bombe dans la rade de Villefranche (AlpesMaritimes). In: Boudouresque, C.F., Jeudy De Grissac, A., Olivier, J. (Eds.), International Workshop on Posidonia oceanica Beds. G.I.S. Posidonie, Marseille, France, pp. 39-44.

Meinesz, A., Boudouresque, C.F., Lefevre, J.R., 1988. A map of the Posidonia oceanica beds of Marina d'Elbu (Corsica, Mediterranean). Mar. Ecol. 9, 243.

Moilanen, A., 2011. On the limitations of graph-theoretic connectivity in spatial ecology and conservation. J. Appl. Ecol. 48, 1543-1547.

Molenaar, H., Barthélémy, D., de Reffye, P., Meinesz, A., Mialet, I., 2000. Modelling architecture and growth patterns of Posidonia oceanica. Aquat. Bot. 66, 85-99.

Molinier, R., Picard, J., 1952. Recherches sur les herbiers de phanérogames marines du littoral méditerranéen français. Ann. Inst. Oceanogr. 27, 157-234.

Montefalcone, M., Albertelli, G., Morri, C., Bianchi, C.N., 2007. Urban seagrass: status of Posidonia oceanica facing the Genoa city waterfront (Italy) and implications for management. Mar. Pollut. Bull. 54, 206-213.

Montefalcone, M., Albertelli, G., Morri, C., Bianchi, C.N., 2010a. Patterns of wide-scale substitution within meadows of the seagrass Posidonia oceanica in NW Mediterranean Sea: invaders are stronger than natives. Aquat. Conserv.: Mar. Freshwat. Ecosyst. 20, 507-515.

Montefalcone, M., Parravicini, V., Vacchi, M., Albertelli, G., Ferrari, M., Morri, C., Bianchi, C.N., 2010b. Human influence on seagrass habitat fragmentation in NW Mediterranean Sea. Estuar. Coast. Shelf Sci. 86, 292-298.

Montefalcone, M., Rovere, A., Parravicini, V., Albertelli, G., Morri, C., Bianchi, C.N., 2013. Evaluating change in seagrass meadows: a time-framed comparison of side scan sonar maps. Aquat. Bot. 104, 204-212.

Montefalcone, M., Morri, C., Parravicini, V., Bianchi, C.N., 2015. A tale of two invaders: divergent spreading kinetics of the alien green algae Caulerpa taxifolia and Caulerpa cylindracea. Biol. Invas. 17, 2717-2728.

Montefalcone, M., Vacchi, M., Carbone, C., Cabella, R., Schiaffino, C.F., Elter, F.M., Morri, C., Bianchi, C.N., Ferrari, M., 2016. Seagrass on the rocks: Posidonia oceanica settled on shallow-water hard substrata withstands wave stress beyond predictions. Estuar. Coast. Shelf Sci.

Niedomysl, T., Elldér, E., Larsson, A., Thelin, M., Jansund, B., 2013. Learning benefits of using 2D versus 3D maps: evidence from a randomized controlled experiment. J. Geogr. 112, 87-96.

Noël, C., Boissery, P., Quelin, N., Raimondino, V., 2012. Cahier Technique du Gestionnaire-Analyse comparée des méthodes de surveillance des herbiers de posidonies. CartOcean, Agence de l'eau RMC, Dreal PACA, Région PACA.

Nowell, M.S., 2014. The Application of Landscape Ecology Techniques for Managing Disturbed Mediterranean Coastal Seascapes. Universitat Autonoma de Barcelona, Barcelona, Spain p. 103.
Odum, E.P., Barrett, G.W., 1971. Fundamentals of Ecology. Saunders, Philadelphia.

Okudan, E.S., Demir, V., Kalkan, E., Karhan, S.U., 2011. Anchoring damage on seagrass meadows (Posidonia oceanica (L.) Delile) in Fethiye-Gocek specially protected area (Eastern Mediterranean Sea, Turkey). J. Coast. Res. 61, 417-420.

Olds, A.D., Connolly, R.M., Pitt, K.A., Pittman, S.J., Maxwell, P.S., Huijbers, C.M., Moore, B.R., Albert, S., Rissik, D., Babcock, R.C., 2016. Quantifying the conservation value of seascape connectivity: a global synthesis. Global Ecol. Biogeogr. 25, 3-15.

Pace, M., Borg, J., Galdies, C., Malhotra, A., 2017. Influence of wave climate on architecture and landscape characteristics of Posidonia oceanica meadows. Mar. Ecol. 38.

Pagès, J.F., Gera, A., Romero, J., Alcoverro, T., 2014. Matrix composition and patch edges influence plant-herbivore interactions in marine landscapes. Funct. Ecol. 28, 1440-1448.

Panayotidis, P., Boudouresque, C.F., Marcot-Coqueugniot, J., 1981. Microstructure de l'herbier de Posidonia oceanica (Linnaeus) Delile. Microstructure of Posidonia oceanica (Linnaeus) beds. Bot. Mar. 24, 115-124.

Parrott, L., Proulx, R., Thibert-Plante, X., 2008. Three-dimensional metrics for the analysis of spatiotemporal data in ecology. Ecol. Inf. 3, 343-353.

Pasqualini, V., Pergent-Martini, C., Clabaut, P., Pergent, G., 1998. Mapping of Posidonia oceanica using aerial photographs and side scan sonar: Application off the Island of Corsica (France). Estuar. Coast. Shelf Sci. 47, 359-367.

Pasqualini, V., Pergent-Martini, C., Pergent, G., 1999. Environmental impact identification along the Corsican coast (Mediterranean sea) using image processing. Aquat. Bot. 65, 311-320.

Pasqualini, V., Clabaut, P., Pergent, G., Benyoussef, L., Pergent-Martini, C., 2000. Contribution of side scan sonar to the management of Mediterranean littoral ecosystems. Int. J. Remote Sens. 21, 367-378.

Pedersen, M.O., Serrano, O., Mateo, M.A., Holmer, M., 2011. Temperature effects on decomposition of a Posidonia oceanica mat. Aquat. Microb. Ecol. 65, 169-182.

Peirano, A., Niccolai, I., Mauro, R., Bianchi, C.N., 2001. Seasonal grazing and food preference of herbivores in a Posidonia oceanica meadow. Sci. Mar. 65, 367-374.

Pergent, G., Romeo, M., Pergent-Martini, C., Mateo, M.A., Boudouresque, C.F., 1994. Primary production, stocks and fluxes in the Mediterranean seagrass Posidonia oceanica. Mar. Ecol. Prog. Ser. 109, 139-146.

Pergent, G., Rico-Raimondino, V., Pergent-Martini, C., 1997. Fate of primary production in Posidonia oceanica meadows of the Mediterranean. Aquat. Bot. 59, 307-321.

Pergent, G., Boudouresque, C.-F., Dumay, O., Pergent-Martini, C., Wyllie-Echeverria, S., 2008. Competition between the invasive macrophyte Caulerpa taxifolia and the seagrass Posidonia oceanica: contrasting strategies. BMC Ecol. 8, 1-13.

Picard, J., 1965. Importance, répartition et rôle du matériel organique végétal issu des prairies de posidonies. Rapports et PV des réunions de la Commission Internationale pour l'Exploration Scientifique de la Méditerranée 18, 91-92.

Pickett, S.T.A., Cadenasso, M.L., 1995. Landscape ecology: spatial heterogeneity in ecological systems. Science 269, 331-334.

Pinna, S., Sechi, N., Ceccherelli, G., 2013. Canopy structure at the edge of seagrass affects sea urchin distribution. Mar. Ecol. Prog. Ser. 485, 47-55.

Pittman, S.J., Kneib, R.T., Simenstad, C.A., 2011. Practicing coastal seascape ecology. Mar. Ecol. Prog. Ser. 427, 187-190.

Pittman, S.J., 2017. Seascape Ecology: Taking Landscape Ecology into the Sea. WileyBlackwell.

Popelka, S., Brychtova, A., 2013. Eye-tracking study on different perception of 2D and 3D terrain visualisation. Cartogr. J. 50, 240-246.

Prado, P., Alcoverro, T., Romero, J., 2009. Welcome mats? The role of seagrass meadow structure in controlling post-settlement survival in a keystone sea-urchin species. Estuar. Coast. Shelf Sci. 85, 472-478.

Remy, F., 2016. Characterization, Dynamics and Trophic Ecology of Macrofauna Associated to Seagrass Macrophytodetritus Accumulations (Calvi Bay, Mediterranean Sea). Université de Liège, Liège, Belgique.

Ricart, A.M., Dalmau, A., Pérez, M., Romero, J., 2015. Effects of landscape configuration on the exchange of materials in seagrass ecosystems. Mar. Ecol. Prog. Ser. 532, 89-100.

Robbins, B.D., Bell, S.S., 1994. Seagrass landscapes: a terrestrial approach to the marine subtidal environment. Trends Ecol. Evol. 9, 301-304.

Robinson, L.M., Elith, J., Hobday, A.J., Pearson, R.G., Kendall, B.E., Possingham, H.P., Richardson, A.J., 2011. Pushing the limits in marine species distribution modelling: lessons from the land present challenges and opportunities. Global Ecol. Biogeogr. 20, 789-802.

Rountos, K.J., Peterson, B.J., Karakassis, I., 2012. Indirect effects of fish cage aquaculture on shallow Posidonia oceanica seagrass patches in coastal Greek waters. Aquacult. Environ. Interact. 2, 105-115.

Rykiel, E.J., 1989. Artificial intelligence and expert systems in ecology and natural resource management. Ecol. Model. 46, 3-8.

Sánchez-Jerez, P., Ramos Esplá, A.A., 1996. Detection of environmental impacts by bottom trawling on Posidonia oceanica (L.) Delile meadows: sensitivity of fish and macroinvertebrate communities. J. Aquat. Ecosyst. Health 5, 239-253.

Sánchez-Jerez, P., Cebrián, C.B., Esplá, A.A.R., 1999. Comparison of the epifauna spatial distribution in Posidonia oceanica, Cymodocea nodosa and unvegetated bottoms: importance of meadow edges. Acta Oecol. 20, 391-405.

Schobesberger, D., Patterson, T., 2008. In: Evaluating the Effectiveness of 2D Vs. 3D Trailhead Maps-A Map User Study Conducted at Zion National Park, United States, 6th ICA Mountain Cartography Workshop. Lenk, Switzerland. pp. 201-205.

Schumaker, N.H., 1996. Using landscape indices to predict habitat connectivity. Ecology $77,1210-1225$.

Šímová, P., Gdulová, K., 2012. Landscape indices behavior: a review of scale effects. Appl. Geogr. 34, 385-394.

Sleeman, J.C., Kendrick, G.A., Boggs, G.S., Hegge, B.J., 2005. Measuring fragmentation of seagrass landscapes: which indices are most appropriate for detecting change? Mar. 
Freshw. Res. 56, 851-864.

Tamburello, L., Benedetti-Cecchi, L., Ghedini, G., Alestra, T., Bulleri, F., 2012. Variation in the structure of subtidal landscapes in the NW Mediterranean Sea. Mar. Ecol. Prog. Ser. 457, 29-41.

Telesca, L., Belluscio, A., Criscoli, A., Ardizzone, G., Apostolaki, E.T., Fraschetti, S., Gristina, M., Knittweis, L., Martin, C.S., Pergent, G., Alagna, A., Badalamenti, F., Garofalo, G., Gerakaris, V., Louise Pace, M., Pergent-Martini, C., Salomidi, M., 2015. Seagrass meadows (Posidonia oceanica) distribution and trajectories of change. Sci. Rep. 5, 12505.

Turner, M.G., 1989. Landscape ecology: the effect of pattern on process. Annu. Rev. Ecol. Evol. Syst. 20, 171-197.

Vacchi, M., Montefalcone, M., Bianchi, C.N., Morri, C., Ferrari, M., 2010. The influence of coastal dynamics on the upper limit of the Posidonia oceanica meadow. Mar. Ecol. 31, $546-554$.

Vacchi, M., De Falco, G., Simeone, S., Montefalcone, M., Morri, C., Ferrari, M., Bianchi, C.N., 2017. Biogeomorphology of the Mediterranean Posidonia oceanica seagrass meadows. Earth Surf. Proc. Landf. 42, 42-54.
Verlaque, M., Nedelec, H., 1983. Biologie de Paracentrotus lividus (Lamarck) sur substrat rocheux en Corse (Méditerranée, France): alimentation des adultes. Vie et Milieu 33, 191-201.

Wolff, T., 1976. Utilization of seagrass in the deep sea. Aquat. Bot. 2, 161-174.

Wu, Z., Wei, L., Lv, Z., 2012. Landscape pattern metrics: an empirical study from 2-D to 3D. Phys. Geogr. 33, 383-402.

Zonneveld, I.S., 1995. Land Ecology: An Introduction to Landscape Ecology as a Base for Land Evaluation, Land Management and Conservation. SPB Academic Publishing, Amsterdam.

Zupo, V., Buia, M.C., Gambi, M.C., Lorenti, M., Procaccini, G., 2006a. Temporal variations in the spatial distribution of shoot density in a Posidonia oceanica meadow and patterns of genetic diversity. Mar. Ecol. 27, 328-338.

Zupo, V., Mazzella, L., Buia, M.C., Gambi, M.C., Lorenti, M., Scipione, M.B., Cancemi, G., 2006b. A small-scale analysis of the spatial structure of a Posidonia oceanica meadow off the Island of Ischia (Gulf of Naples, Italy): Relationship with the seafloor morphology. Aquat. Bot. 84, 101-109. 